\title{
Políticas territoriais na América do Sul: infraestruturas de conexão e repercussões em regiões periféricas
}

\author{
Aldomar Arnaldo Rückert \& Camilo Pereira Carneiro
}

\section{Introdução}

O presente artigo apresenta uma análise de políticas territoriais em processos de integração sul-americana. Para tanto aborda-se os vários regionalismos e, em especial, o regionalismo pósneoliberal dos anos 2000 assim como o projeto da América do Sul como uma região geopolítica, suas assimetrias internas e possíveis repercussões territoriais de projetos de redes de circulação em regiões periféricas. Por fim trata-se dos rumos atuais da integração sul-americana e das infraestruturas de conexão.

Para procurar caracterizar e explicitar possíveis relações entre políticas repercussões territoriais em regiões periféricas através de projetos e/ou da implantação de infraestruturas de conexão e fluidez apresenta-se quatro perspectivas. $\mathrm{Na}$ primeira procura-se responder como se caracterizam os fundamentos do velho regionalismo (anos 1950-1970), o regionalismo aberto (anos 1990), o regionalismo pós-neoliberal (anos 2000-...) e o ideário da América do Sul como uma região geopolítica, "isto é, uma entidade política transnacional dotada de unidade mínima e arcabouço institucional baseados em princípios e macro-objetivos comuns nas relações internacionais". (COSTA, 2009). Correspondem a estes períodos a criação da Iniciativa para a Integração da Infraestrutura Regional SulAmericana - IIRSA (anos 1990) e sua posterior transformação em Conselho Sul-Americano de Infraestrutura e Planejamento - COSIPLAN da União das Nações Sul-Americanas - UNASUL (anos 2000), instituições que têm apoiado e articulado governos nacionais para transformar usos do território através da implantação de infraestruturas de conexão, principalmente aquelas vertidas para o exterior.

Na segunda perspectiva apresentam-se algumas assimetrias socioeconômico-territoriais entre os países da América do Sul, principalmente entre o Brasil e seus vizinhos, caracterizadas por fraturas e descontinuidades populacionais e econômicas que caracterizam as heterogeneidades internas à região continental onde espaços periféricos interioranos estão ainda fortemente desconectados das regiões centrais.

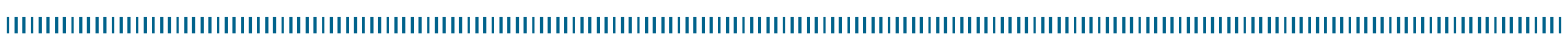
Como citar este artigo:

RÜCKERT, Aldomar A. \& CARNEIRO, Camilo Pereira. "Políticas territoriais na América do Sul: infraestruturas de conexão e repercussões em regiões periféricas”. In: RÜCKERT, A. A.; SILVA, A. C. P. da; SILVA, G. de V. (Orgs.). Geografia Política, Geopolítica e Gestão do Território: integração sul-americana e regiões periféricas. Porto Alegre: Editora Letra1, 2018, p. 11-39 DOI 10.21507/9788563800367-01 
$\mathrm{Na}$ terceira perspectiva procura-se responder de que maneira alguns projetos de infraestruturas de conexão, a maioria pertencente à carteira de projetos do COSIPLAN e à Agenda de Projetos Prioritários de Integração - API -, têm repercutido em regiões periféricas. Para procurar responder a esta questão apresenta-se, resumidamente, três casos de infraestruturas de conexão em regiões periféricas:o projeto da estrada Villa Tunari San Ignacio de Mojos e a Terra Indígena TIPNIS, na Bolívia; a Ruta Nacional 150, na Argentina e projetos de melhorias de rodovias no Escudo das Guianas e na Floresta Amazônica.

Os três casos escolhidos, na Bolívia, na Argentina e no Escudo das Guianas atendem a critérios operacionais de projetos de pesquisa sobre processos de transfronteirizações em curso citados no início do trabalho. Procurou-se evidenciar exemplos de regiões diferenciadas entre si, tendo como ponto comum tratar-se de espaços periféricos distantes dos grandes centros urbanos e dos principais corredores de circulação. Além disso, os casos são significativos em si mesmos, visto que no exemplo do Corredor Bioceânico Porto Alegre (Brasil) - Coquimbo (Chile) a Ruta Nacional 150, na Província de San Juan (Argentina), é muito significativa por tratar-se do último elo de ligação a completar-se antes do início dos trabalhos de construção do túnel Água Negra, nos Andes. O caso de TIPNIS, na Bolívia, reflete a reação das comunidades tradicionais na defesa de seus direitos territoriais e contra a construção de uma rodovia que poderá cruzar o Território Indígena e Parque Nacional Isiboro Sécure. Já o caso de rodovias precárias no Planalto das Guianas e o baixo investimento recebido até o momento podem refletir o isolamento entre os Estados nacionais além das próprias características da região que é ocupada, predominantemente, no litoral, estando o interior amazônico relativamente isolado e com deficiências de infraestruturas. A abertura informal (os prefeitos das cidades de Oiapoque e Saint-Georges tomaram a iniciativa sem que autoridades da esfera federal participassem) da ponte internacional Brasil-Guiana Francesa, sobre o rio Oiapoque, no ano de 2017, pouco contribui para alterar o cenário de isolamento entre os Estados nacionais da região, visto as várias restrições que a França metropolitana impõe à entrada de brasileiros na Guiana Francesa.

$\mathrm{Na}$ quarta e última perspectiva apresenta-se elementos para caracterizar os rumos atuais da proposta da América do Sul como uma região geopolítica e das infraestruturas de conexão, fortemente condicionados à crise mundial pós2008, mais notadamente a partir dos anos 20112012. Neste contexto atual e claramente no Brasil pós-2016 inexiste uma política externa para a América do Sul, enquanto que a China avança com investimentos sobre a região e os BRICS enfrentam uma contrarreação com a definição do Atlântico Sul como espaço estratégico de relevância crescente para os EUA.

Analisar políticas territoriais através dos usos políticos do território - como projeções de poder e controle territorial (SANCHEZ, 1992) ${ }^{1}$ - em processos integracionistas através de redes de circulação - infraestruturas de conexão supranacional - permite-nos enfocar como agem conjuntos de atores territoriais e como estas ações podem repercutir territorialmente. Além disso, trata-se de conhecer as estratégias e os recursos que cada ator ou conjunto de atores mobilizam para atingir seus objetivos. (RAFFESTIN, 1993; ROSIÈRE, 2007). Os usos políticos do território e ações públicas territoriais de Estados nacionais, governos regionais, da UNASUL e do COSIPLAN, através de diferentes escalas de poder e gestão compartilhadas entre diferentes níveis de governos podem - ou não - estar associados a repercussões territoriais que, por sua vez, podem se constituir como novas questões para análise territorial. Para tanto, adota-se uma perspectiva de que o espaço geográfico é descontínuo, o que se revela significativo na América do Sul.

||||||||||||||||||||||||||||||||||||||||

1 "A política territorial se configura pelo conjunto de abordagens estratégicas, a médio e longo prazo, assim como pelas correspondentes formulações de atuação dirigidas a intervir sobre o território, a fim de que assuma as formas que sejam adequadas ao conjunto dos interesses que controlam o poder político". (SANCHEZ, 1992, p. 72). 
No cenário sul-americano, as regiões periféricas (em oposição às regiões e pontos nodais centrais via de regra localizadas nas regiões costeiras) podem ser compreendidas como fraturas e descontinuidades, com fortes desigualdades territoriais em cenários nacionais e supranacionais, com baixas densidades de capital, populacionais, técnicas e informacionais e com pouca fluidez nas circulações, o que foi definido por Santos e Silveira (2003) como espaços opacos. As localizações distantes de regiões periféricas em processos de integrações supranacionais tendem a ser relativizadas (o espaço se torna relativo quando as distâncias podem diminuir pelo aumento da fluidez da circulação) com a implantação e/ou melhorias de novas redes de circulação - quando houver investimentos principalmente em regiões fronteiriças. Importante ter em conta que o processo de criação de fluidez, como lembram Santos e Silveira (2003) é seletivo e não-igualitário, pois as regiões onde se situam produções destinadas à exportação e ao comércio distante têm prioridade nesses equipamentos da infraestrutura estratégica.

Em regiões fronteiriças, quando coexistem médias ou altas densidades de capital, técnicas e populacionais em ambos os lados dos Estados nacionais há a possibilidade de surgirem processos intensos de transfronteirização, isto é, articulações e conexões supranacionais que podem abranger desde a vida cotidiana das populações até a implantação de infraestruturas que possibilitam as conexões transfronteiriças. Este é o caso do Eixo MERCOSUL-Chile, onde estes indicadores coexistem com uma vida de relações transfronteiriças intensas. Por outro lado, onde as regiões fronteiriças são espaços opacos e distantes dos centros políticos ou econômicos, a fluidez para o interno e externo pode inexistir, tendendo para situações de periferias extremas desconectadas de processos de integração e transfronteirização. Este é o caso da rodovia projetada pelo governo boliviano para passar através do Território Indígena e Parque Nacional Isiboro Sécure, TIPNIS, localizada em uma região interiorana entre os departamentos de Cochabamba e Beni, Bolívia, bem como do Escudo das Guianas, vasta região com povoamento litorâneo e infraestruturas interiores precárias.

Seguem os quatro tópicos que procuram aprofundar as quatro perspectivas de análise. Em primeiro lugar aborda-se a transição do velho regionalismo (1950-1970) ao regionalismo pós-neoliberal (2000), passando pelo ideário da construção da América do Sul como uma região geopolítica. Em segundo trata-se das assimetrias territoriais entre o Brasil e os países vizinhos e suas fraturas e descontinuidades. Em terceiro procura-se trazer algumas observações a como projetos de infraestruturas de conexão podem repercutir em regiões periféricas através de três exemplos: o projeto da rodovia Villa Tunari - San Ignacio de Mojos, através do Território Indígena e Parque Nacional Isiboro Sécure, TIPNIS, Bolívia; o Corredor Bioceânico Porto Alegre (Brasil) Coquimbo (Chile), no Eixo MERCOSUL-Chile; e a Ruta Nacional 150, Argentina e o Eixo das Guianas, através dos estados do Amapá, Amazonas e Roraima (Brasil), Guiana Francesa, Suriname e Guiana, na Floresta Amazônica, com suas infraestruturas precárias. Por fim, seguem considerações sobre os rumos atuais da integração sul-americana e das infraestruturas de conexão, cenário onde percebe-se, atualmente, uma relativa ausência de continuidade do ideário da América do Sul como uma região geopolítica.

\section{O velho regionalismo (anos 1950-1970), o regionalismo aberto (anos 1990), o regionalismo pós-neoliberal (2000) e o projeto da América do Sul como uma região geopolítica}

Os ideais da integração latino-americana não são novos e nem recentes. Eles remontam ao período de independência das ex-colônias espanholas no início do século XIX. Simón Bolívar, um dos líderes das independências, desejava que as ex-colônias se tornassem uma federação sob um governo único seguindo a experiência do federalismo norteamericano. O sonho bolivariano de formar uma república moderna, sem escravidão, do México à 
Terra do Fogo, de certa forma, continua vivo, expresso em um conjunto de linhas de atuação política como, por exemplo, a união dos países latino-americanos como se verá ao tratar-se da UNASUL - União das Nações Sul-Americanas. (SOUZA, 2010).

No que tange aos processos de integração regional, a atuação da Comissão Econômica para a América Latina (CEPAL) desde o final da década de 1940 reside na formulação do velho regionalismo ou regionalismo fechado, isto é a criação de blocos regionais de comércio com a finalidade de promover o desenvolvimento através da integração econômica. Esta primeira fase do regionalismo latino-americano (1950-1970) ganhou força com a assinatura do Tratado de Roma em 1957 (OLIVEIRA, 2014, p. 9), precursor da União Europeia. O Pacto Andino (criado em 1969, por Bolívia, Colômbia, Equador, Peru, Venezuela e Chile ${ }^{2}$ ) e o MERCOSUL (criado em 1991, por Brasil, Argentina, Paraguai e Uruguai) são dois exemplos da formação de blocos comerciais / uniões aduaneiras sob a inspiração cepalina.

Uma segunda fase do regionalismo latinoamericano passou a ser difundida pela CEPAL nos anos 1990. Essa fase ficou conhecida como regionalismo aberto, isto é "um processo de crescente interdependência econômica em nível regional, impulsionado tanto por acordos preferenciais de integração como por outras políticas num contexto de abertura e desregulamentação, com o objetivo de aumentar a competitividade dos países da região e de constituir, dentro do possível, um cimento para uma economia internacional mais aberta e transparente". (CEPAL, 1994, p. 2).

Ao contrário do período anterior do velho regionalismo as proposições do regionalismo aberto caracterizam-se por conciliar as políticas de integração regional com as que visam promover a competitividade internacional e a abertura das economias. (CORAZZA, 2006, p. 135-152). Esta fase mais recente relaciona-se à difusão da onda

||||||||||||||||||||||||||||||||||||||||

2 O Chile abandonou o bloco em 1976, durante a ditadura do general Pinochet. Atualmente o país é membro associado, uma das condições para retornar ao bloco. do novo regionalismo, que se fortaleceu com as políticas regionais da União Europeia desde a década de 1980 com as concepções acerca do papel das regiões como epicentros na economia global. (FERNANDEZ, 2007).

Uma das explicitações mais visíveis da implementação das linhas de ação do regionalismo aberto, especialmente na América do Sul, é a IIRSA - Iniciativa para a Integração da Infraestrutura Regional Sul-Americana. A iniciativa foi lançada durante a I Cúpula de Presidentes da América do Sul em Brasília, entre 31 de agosto e $1^{\circ}$ de setembro de 2000, dentro dos moldes do Consenso de Washington, preconizados pelo Banco Interamericano de Desenvolvimento, em coordenação com a CAF (Corporación Andina de Fomento) nos governos Fernando Henrique Cardoso (anos 1994-2002). Os Eixos Nacionais de Integração e Desenvolvimento do Brasil vertidos para o exterior (denominados desde a década de 1970 de corredores de transporte destinados à exportação de grãos e minérios pelos portos do Brasil) serviram de modelo para a proposta da integração sul-americana. Implementou-se uma visão convencional dominante do regionalismo aberto, isto é, a formação de uma área de livre comércio com a implementação de corredores bioceânicos para interligar o subcontinente, principalmente, ao mercado asiático ${ }^{3}$. A IIRSA nasce sob esta concepção, isto é, a lógica das privatizações e o Estado mínimo na economia ${ }^{4}$. Um segundo exemplo pode ser associado às linhas políticas do regionalismo aberto da CEPAL, a Aliança do Pacífico, o mais recente bloco comercial criado em 2012, por Chile, Colômbia, México e Peru, visando

IIIIIIIIIIIIIIIIIIIIIIIIIIIIIIIII!

3 Atualmente são 9 os Eixos de Integração e Desenvolvimento: Amazonas, Andino, Capricórnio, Sul, Escudo das Guianas, Hidrovia Paraná-Paraguai, Interoceânico, MERCOSUL-Chile e Peru-BolíviaBrasil.

4 O Comitê de Coordenação Técnica da IIRSA foi composto pelas agências financeiras multilaterais BID-Banco Interamericano de Desenvolvimento (com forte influência dos Estados Unidos que participam com $30,5 \%$ dos seus fundos de US $\$ 170,9$ bilhões), CAF - Corporação Andina de Fomento, atualmente Banco de Desenvolvimento da América Latina - e o FONPLATA - Fundo Financeiro para o Desenvolvimento da Bacia do Prata -, que passou a ter grande controle das ações da Iniciativa. 
uma Área de Livre Comércio com a livre circulação de serviços, de capitais e de pessoas.

No final da década de 1990 e início dos anos 2000 as consequências da adoção de medidas do Consenso de Washington e do Fundo Monetário Internacional foram prejudiciais aos países latino-americanos, então chamados de debtcountries, com medidas ortodoxas direcionadas à redução do tamanho do Estado, privatizações, desnacionalização de empresas, redução de direitos sociais, etc. Seguiram-se violentas comoções sociais generalizadas, manifestações de massa, greves que paralisaram as economias nacionais, tentativas de golpes de Estado como na Venezuela e no Equador, etc. Porém, como afirmou Moniz Bandeira (2002), essa crise já pré-existia desde as décadas de 1960 e 1970, tendo sido agravada com aquelas medidas. A dívida externa permaneceu como um problema para toda a América Latina, principalmente para o Brasil, o que continua até o presente.

A eleição dos governos populares com orientação de centro-esquerda na América do Sul nos anos 2000 deve-se, em grande parte, às eclosões sociais que se seguiram à crise social e econômica provocadas por medidas ortodoxas do Consenso de Washington ${ }^{5}$. No entender de Pecequillo (2016, p. 237), todos esses fatores mencionados

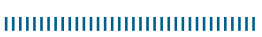

5 No Brasil, elegeu-se Luiz Inácio Lula da Silva em 2002 pelo Partido dos Trabalhadores; na Argentina, Néstor Kirchner em 2003 pela Frente para a Vitória, com amplo apoio do Partido Justicialista (peronista); no Uruguai, Tabaré Vásquez em 2005 pela coalizão Encuentro Progresista - Frente Amplio - Nueva Mayoría; na Bolívia, Evo Morales em 2006 pelo Movimiento al SocialismoInstrumento Político por la Soberanía de los Pueblos; no Equador, Rafael Correa em 2006 pelo Movimiento Alianza PAIS - Patria Altiva i Soberana - e no Paraguai, Fernando Lugo em 2008, pela Alianza Patriótica para el Cambio. O primeiro governo popular foi o de Hugo Chávez (Venezuela) que havia sido eleito em 1998 pelo Movimiento Quinta República. Com maior ou menor grau os governos populares atravessaram dificuldade, notadamente as instabilidades políticas na Venezuela. Hugo Chávez, que já havia tentado um golpe de Estado contra o governo de Carlos Andrés Pérez em 1992, concorreu a eleições em 1998, tendo assumido a Presidência por quatro períodos presidenciais até sua morte em 2013. Em 2002 Chávez sofrera um golpe de Estado que durou 47 horas. Seguiram-se as deposições de Lugo no Paraguai, em 2012, e de Dilma Rousseff no Brasil, em 2016. Governos eleitos democraticamente foram objeto de ações legislativas e judiciárias que são controversas e consideradas por correntes progressistas como golpes de Estado contra o Estado democrático e de direito. somados à crise latino-americana e ao vácuo de poder estadunidense permitiram a emergência e consolidação de dois polos com agendas de autonomia: Hugo Chávez na Venezuela e Lula da Silva no Brasil. Ambos com focos em temas sociais, políticos, econômicos e estratégicos, visando a correção de assimetrias internas, desenvolvimento econômico e a retomada de uma política externa autônoma. A opção do México pelo NAFTA - North American Free Trade Agreement -, em 1994, a rejeição à proposta norte-americana da Free Trade Area of the Americas (FTAA ou ALCA) pela maioria dos governos latino-americanos na $4^{a}$ Cúpula das Américas em novembro de 2005, em Mar del Plata (Argentina), bem como o foco da política externa norte-americana no Afeganistão e no Iraque, no contexto internacional, confluíram para que os novos governos sul-americanos adotassem políticas externas autônomas visando valorizar a identidade sul-americana. (NERY, 2016, p. 64).

\section{O projeto da América do Sul como uma região geopolítica}

Dentre os macro-objetivos comuns aos países da América do Sul, uma nova política externa de vários governos passou a ocupar grande destaque no cenário geopolítico da região continental. Esta nova política contou com expressiva liderança do governo Lula da Silva do Brasil, notadamente através do próprio presidente Lula, do Chanceler Celso Amorim, do diplomata Samuel Pinheiro Guimarães, então Secretário-geral das Relações Exteriores, e do Assessor Especial da Presidência para Assuntos de Relações Exteriores, Marco Aurélio Garcia. Seguiu-se a formulação pelos governos populares do regionalismo pósneoliberal sul-americano com ações diplomáticas que resultaram na criação da CASA - Comunidade Sul-Americana de Nações, em 2004, em Cuzco, Peru, posteriormente transformada na União Sul-Americana de Nações - UNASUL (23 de maio de 2008, Brasília; ver mapa 1).

Com importante foco na busca pela redução das assimetrias regionais, no alinhamento com os países em condições socioeconômicas 
Mapa 1. América do Sul: um projeto de região geopolítica.

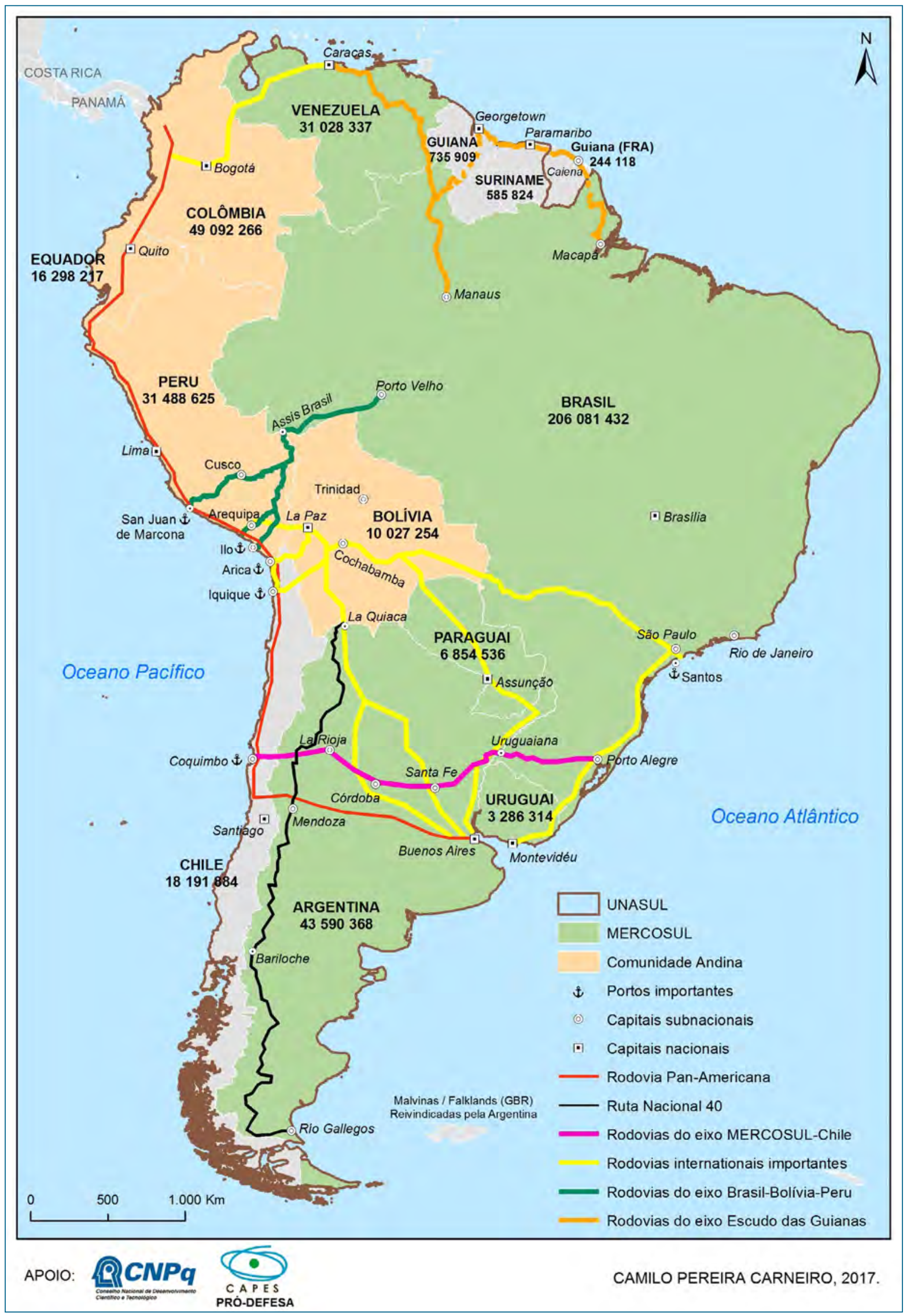


relativamente semelhantes no BRICS (Brasil, Rússia, Índia, China e África do Sul) e novas relações Sul-Sul, a UNASUL avançou rumo a mudanças nas concepções geopolíticas da América do Sul. O novo regionalismo sul-americano pósneoliberal, como informa Nery (2016, p. 65), reconhece a importância do comércio, mas agrega fatores estratégicos como segurança, solução de conflitos, defesa dos direitos humanos, vigência da democracia, desenvolvimento socioeconômico, proteção ao meio ambiente e integração física e energética. Por sua vez, o Conselho SulAmericano de Defesa criado em 2008, a partir de uma proposta brasileira, procura ser um "catalisador da identidade sul-americana de defesa", construindo convergência entre princípios e valores, e superando os resquícios da época da Guerra Fria. (DINIZ, 2015).

A UNASUL vinha se caracterizando como um espaço multilateral de coordenação política, um instrumento de governança regional, englobando a ALBA - Aliança Bolivariana para os Povos da Nossa América, a CAN - Comunidade Andina -, o MERCOSUl e a Aliança do Pacífico. Além disto, a OCTA - Organização do Tratado de Cooperação Amazônico (criada em 1978, como Tratado de Cooperação Amazônica) - é outra experiência institucional regional que poderia trazer implicações para a consolidação da UNASUL. A Organização distingue-se como uma questão estratégica regional da região amazônica sob o ponto de vista econômico, de recursos, climático e de segurança, este em função da questão dos conflitos na região colombiana. (COSTA, 2010, p. 127). Ao mesmo tempo, a UNASUL vinha reconhecendo as características heterogêneas dos diversos regionalismos sul-americanos, a não-convergência dos regimes comerciais e as pluralidades das ideologias na América do Sul.

As ações pró-integração sul-americana nesse início de séculoXXI vinham baseando-se não apenas nas identidades comuns, no compartilhamento das bacias hidrográficas do Amazonas, Orinoco e do Prata, nas proximidades e contiguidades geográficas (em que pesem as grandes assimetrias entre os países) e em diplomacias pró-ativas com caráter autonomista em relação à área de influência imediata dos Estados Unidos. Ao circunscrever o processo de integração à América do Sul, "o Brasil resgatou um conceito essencialmente geopolítico e geoestratégico". (NERY, 2016, p. 63).

A IIRSA, provavelmente o melhor exemplo dos resultados da implementação das teses do regionalismo aberto da CEPAL, sofreu modificações político-institucionais com o advento do regionalismo pós-neoliberal assumido por um grande número de governos de centro-esquerda da UNASUL. Os governos sul-americanos, ao discordar da abordagem puramente comercial dos eixos da então IIRSA buscaram um maior controle político sobre o tema da infraestrutura, incorporando a Iniciativa ao Conselho SulAmericano de Infraestrutura e Planejamento COSIPLAN - da UNASUL em $2009^{6}$.

As diretrizes político-estratégicas do COSIPLAN afastaram-se das agências financiadoras multilaterais, como os já mencionados BID, CAF e FONPLATA que representavam - e continuam a representar - o regionalismo aberto e a influência dos EUA na América do Sul. O Conselho passou a considerar critérios como consolidação de redes de conectividade com alcance regional e sinergias transfronteiriças. (PADULA, 2014, p. 324-328)7.

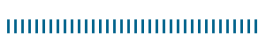

6 Dentre os objetivos do COSIPLAN constam: "Promover a conectividade da região a partir da construção de redes de infraestrutura para sua integração física, atendendo aos critérios de desenvolvimento social e econômico sustentável, preservando o meio ambiente e o equilíbrio dos ecossistemas; aumentar as capacidades e o potencial da população local e regional através do desenvolvimento de infraestruturas, a fim de melhorar sua qualidade e expectativa de vida; conceber estratégias de planejamento regional para desenvolvimento de infraestrutura". Disponível em: <http://www.iirsa.org/Page/Detail?menuItemId=120 >

7 O perfil da Carteira de projetos da UNASUL-COSIPLAN é composto, atualmente, por 581 projetos distribuídos entre os doze países membros, com inversão estimada em US \$191.420 milhões, distribuídos em 47 Grupos de Projetos em nove Eixos de Integração e Desenvolvimento. (COSIPLAN, 2016, p. 9). Na III Reunião de Presidentes da América do Sul em Cuzco, Peru, 2004, quando da criação da Comunidade Sul-Americana de Nações, CASA, a IIRSA foi reafirmada, adotando-se uma Agenda de Implementação Consensuada, ou Agenda de Projetos Prioritários de Integração (API), composta por 31 projetos estruturados (redes de conectividade física com alcance regional distribuídos por diferentes eixos de integração) conformados por 103 projetos individuais concentrados, principalmente, no setor de transportes, 
Da parte do governo brasileiro, durante os mandatos de Lula da Silva, o Banco estatal BNDES assumiu importante papel na política externa como fonte de financiamento de longo prazo para as construtoras brasileiras ${ }^{8}$ para a realização de obras do Programa de Aceleração do Crescimento PAC - no país e na região sul-americana exportando bens e serviços de engenharia e construção civil, promovendo a internacionalização de empresas brasileiras. (PAZ, 2015).

O ideário da América do Sul como uma região geopolítica pode ser compreendido como uma inovação territorial no subcontinente, uma das mais importantes após o fim da Guerra Fria, porém agora em crise. A incorporação das propostas neoliberais da IIRSA como uma base comum para a promoção das infraestruturas de conexão por governos sul-americanos mostrou-se um projeto audacioso por parte das diplomacias de Brasil, Argentina e Venezuela, principalmente. Entretanto, a região caracterizase por profundas assimetrias territoriais que passaram a constar no ideário do COSIPLAN sob o tema do desenvolvimento regional. Ressalta-se que o cenário macrorregional é muito complexo e o próprio projeto do COSIPLAN depende de investimentos que podem demorar a ocorrer, tendo em vista o cenário de crise global pós-2008.

\section{As assimetrias territoriais entre Brasil e América do Sul: fraturas e descontinuidades}

A região América do Sul é, no plano interno, um território fortemente assimétrico, caracterizado por fraturas e descontinuidades socioeconômicas. Importante, neste sentido, é examinar possíveis repercussões em regiões periféricas, espaços distantes dos grandes centros produtores e consumidores, quando processos de

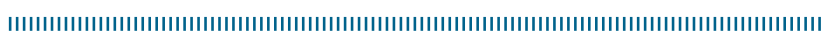
nas modalidades de estradas e rios navegáveis. (COSIPLAN. API. 2016. Grifos dos autores).

8 Trata-se das empresas Odebrecht, Andrade Gutierrez, Camargo Correa, Queiroz Galvão, OAS, Carioca e EIT, todas envolvidas em escândalos de corrupção no Brasil e em países da América do Sul e Central. construção de infraestruturas de conexão visam, primordialmente, construir corredores bioceânicos Atlântico-Pacífico em escala sul-americana para conectar regiões produtoras de commodities a portos que dão acesso aos mercados asiáticos, mais facilmente e a um menor custo. A riqueza produtiva agrícola e industrial e as melhores condições de vida da população concentram-se nas regiões litorâneas, enquanto que baixos indicadores de PIB e de IDH encontram-se dispersos por vastas regiões periféricas interioranas.

As assimetrias sócio-econômico-territoriais entre os países membros da UNASUL são apontadas como a principal causa da fragilidade da integração sul-americana. (COSTA, 2010). Dados do Banco Mundial para 2016 atestavam as grandes disparidades dos valores do Produto Interno Bruto entre o Brasil e seus vizinhos ${ }^{9}$. A Bolívia, por exemplo, é um dos países mais pobres da América do Sul, com IDH médio juntamente com o Paraguai. Em 2014, 45\% da população da Bolívia (que totalizava 10.631.490 habitantes) encontrava-se abaixo da linha de pobreza. (INDEX). Os índices de desenvolvimento humano (IDH de 2000 / 2001) de municípios brasileiros de estados vizinhos da Bolívia, em sua maioria, estavam acima de 0,69 (altos e muito altos), enquanto todos os municípios bolivianos estavam nos extratos inferiores, isto é, médios e baixos. (BRUSLÉ, 2005, p. 533). As assimetrias entre Bolívia e Brasil revelam-se, igualmente, nos fluxos migratórios: um expressivo crescimento do número de cidadãos bolivianos que emigraram quase 150.000 segundo dados da Polícia Federal brasileira - para o Brasil num curto período de seis anos, entre 2008 e 2014. (UEBEL, 2015).

No plano do comércio intrarregional, dados da Associação Latino-Americana de Integração (ALADI) demonstram que as exportações do Brasil

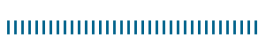

9 De acordo com os dados do Banco Mundial de 2016, os maiores contrastes estão entre o Brasil (US\$1,7 trilhões), a região dos Andes - como o Equador (US\$ 97,8 bilhões) e o Planalto das Guianas -, onde localizam-se os menores valores da América do Sul - na Guiana (US\$ 3,4 bilhões) e no Suriname (US\$ 3,6 bilhões). Já na Bacia do Prata os valores do PIB elevam-se na Argentina (US\$ 545,8 bilhões) e declinam no Paraguai (US $\$ 27,4$ bilhões) e no Uruguai (US\$ 52,4 bilhões). (WORLD BANK). 
para os países da América do Sul no período 20022016 aumentaram seis vezes, tendo passado de US $\$ 7,4$ bilhões para US $\$ 45,2$ bilhões em 2011 , sendo Argentina, Chile e Venezuela os principais países importadores. As principais importações do conjunto dos países vizinhos pelo Brasil, por sua vez, cresceram pouco mais de duas vezes entre 2002 e 2016, passando de US $\$ 8,09$ bilhões em 2002 para US\$19,43 em 2016, sendo que Argentina, Chile e Bolívia são os países que mais exportam para o Brasil.

Os fluxos de cargas rodoviárias de exportação / importação do Brasil com os países vizinhos pelo modal rodoviário concentra-se na macrorregião transfronteiriça da Bacia do Prata / Eixo do MERCOSUL. Cabe destacar que o percentual de estradas não pavimentadas na América do Sul é de aproximadamente $50 \%$, o que faz com que o transporte terrestre eleve o custo comercial. (BOWN, 2017). No âmbito da conexão viária, a grande concentração de cidades gêmeas na fronteira brasileira com Bolívia, Paraguai, Argentina e Uruguai - das 32 cidades-gêmeas entre o Brasil e os países vizinhos, 23 delas concentram-se na Bacia do Prata - dá-se em 16 pontos de passagens internacionais, cabendo a Foz do Iguaçu-BR / Ciudad del Este-PY o maior volume de tráfego de cargas: 182.257 caminhões registrados no ano de 2016 nos dois sentidos de exportação / importação. As cidades gêmeas de Uruguaiana-BR / Paso de los Libres-ARe São BorjaBR / Santo Tomé-AR apresentaram o segundo e o terceiro maiores volumes de caminhões em 2016, 160.718 e 61.735 , respectivamente. (ABTI).

As regiões periféricas - sendo algumas delas transfronteiriças - do vasto espaço interiorano da América do Sul são bons exemplos das fraturas, descontinuidades e desigualdades territoriais da região-continente. Espaços opacos e distantes, com baixos índices populacionais e com fracos IDHs, são um dos grandes desafios para projetos de infraestruturas de conexão, visto que em grande parte da América do Sul eles tendem a ser apenas espaços de passagem de mercadorias com poucas perspectivas de articulações e conexões com processos de desenvolvimento regional.

\section{Repercussões de projetos de infraestruturas de conexão em regiões periféricas}

Neste tópico procura-se responder como alguns projetos de infraestruturas de conexão (a maioria pertencente à carteira de projetos do COSIPLAN e Agenda de Projetos Prioritários de Integração API) têm repercutido em regiões periféricas. Para responder a esta questão apresenta-se três casos de infraestruturas de conexão em regiões periféricas: a) o projeto da rodovia Villa Tunari - San Ignacio de Mojos, através do Território Indígena e Parque Nacional Isiboro Sécure, TIPNIS, na região subandina e amazônica, nos departamentos de Beni e Cochabamba, entre corredores do Eixo Brasil-Bolívia-Peru e do Eixo Interoceânico Central (corredor Santos-BR - Santa Cruz de la SierraBO - La Paz-BO), com improváveis elos a serem concluídos em virtude de conflitos territoriais (ver mapa 2); b) a Ruta Nacional 150, que cruza o eixo estruturador do território argentino - a Ruta Nacional 40, na Província de San Juan, último elo a interligar o Brasil, a Argentina e o Chile através do futuro túnel Água Negra, nos Andes, na região desértica de Cuyo e Sierras Pampeanas, Argentina, passando junto aos parques naturais Talampaya e Ischigualasto e compondo o Corredor Bioceânico Porto Alegre-BR - Coquimbo- $\mathrm{CH}$, no Eixo MERCOSUL-Chile (ver mapa 2); e c) projetos de melhorias de estradas que destinam-se a interligar o Brasil, a Guiana Francesa, o Suriname e a Guiana no Planalto das Guianas e Floresta Amazônica, no Eixo Escudo das Guianas (ver mapa 4).

\section{A rodovia Villa Tunari - San Ignacio de Mojos: resistência indígena e conflitos territoriais}

Apesar da Bolívia aparecer em sexto lugar quanto ao número de projetos do COSIPLAN, o seu território é perpassado por cinco Eixos: Andino, Capricórnio, Hidrovia Paraguai-Paraná, Interoceânico Central e Peru-Brasil-Bolívia, o que o caracteriza como um centro de coesão e dispersão de fluxos em escala continental. (PFRIMER, 2011). O Eixo Peru-Brasil-Bolívia visa ligar através de 
Mapa 2. Corredores bioceânicos nos eixos Central e MERCOSUL-Chile com as localizações do projeto da rodovia Villa Tunari - San Ignacio de Mojos (TIPNIS, Bolívia) e Ruta Nacional 150 na Argentina,com a localização dos parques naturais Talampaya e Ischigualasto.

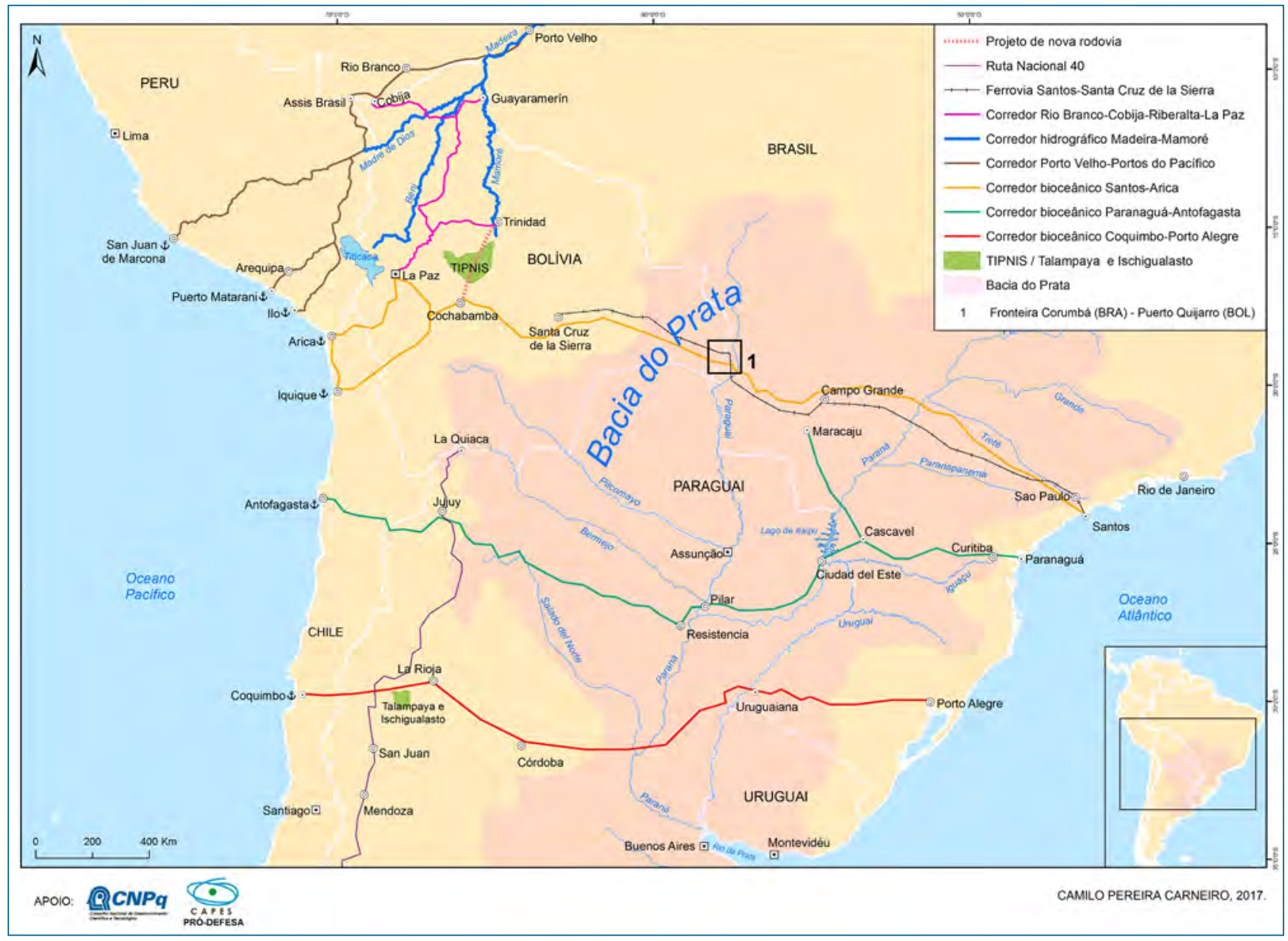

rodovias e vias navegáveis a região produtora de soja nos estados de Rondônia e Acre (região Amazônica, noroeste do Brasil) aos departamentos bolivianos de Beni e Cochabamba, relativamente isolados entre si, no centro do país e à capital La $\mathrm{Paz}$, e dali aos portos chilenos de Arica e Iquique e aos portos do sul do Peru. Nesse contexto, a Rodovia do Pacífico, por exemplo, concluída em 2011, une a cidade de Assis Brasil, no estado do Acre-BR, na tríplice fronteira Brasil-BolíviaPeru, pelos Andes peruanos, através da região de Cuzco, até os portos peruanos de Ilo, Marcona e Matarani. O Eixo Interoceânico, por sua vez, visa interligar a costa do Pacífico na região portuária de Antofagasta e Arica, no extremo norte do Chile, departamentos do sul do Peru e a quase totalidade da Bolívia, do Paraguai e dos estados do centro-sul do Brasil, notadamente os estados industriais da costa atlântica, como Paraná, São Paulo e Rio de Janeiro. (COSIPLAN, 2016).

A Bolívia, juntamente com estados do oeste brasileiro, representaria uma espécie de núcleo ou coração central - o Heartland - da América do Sul, na visão de geopolíticos tradicionais brasileiros. O General Mário Travassos (TRAVASSOS, 1935), por exemplo, propôs de forma pioneira no Brasil, na década de 1930 uma adaptação do conceito de Heartland de Halford Mckinder para a América do Sul ao tratar da projeção do Brasil no subcontinente. A contribuição original de Travassos foi, posteriormente, ampliada por Golbery do Couto e Silva, que propôs uma compartimentação geopolítica da América do Sul na qual o Heartland, ampliado, foi denominado de Área Continental de Soldadura, correspondendo aos atuais estados do Mato Grosso do Sul, Mato 
Foto 1. Portal de entrada na cidade de Puerto Quijarro, extremo-leste do Departamento de Santa Cruz, Bolívia junto à fronteira com o Brasil.

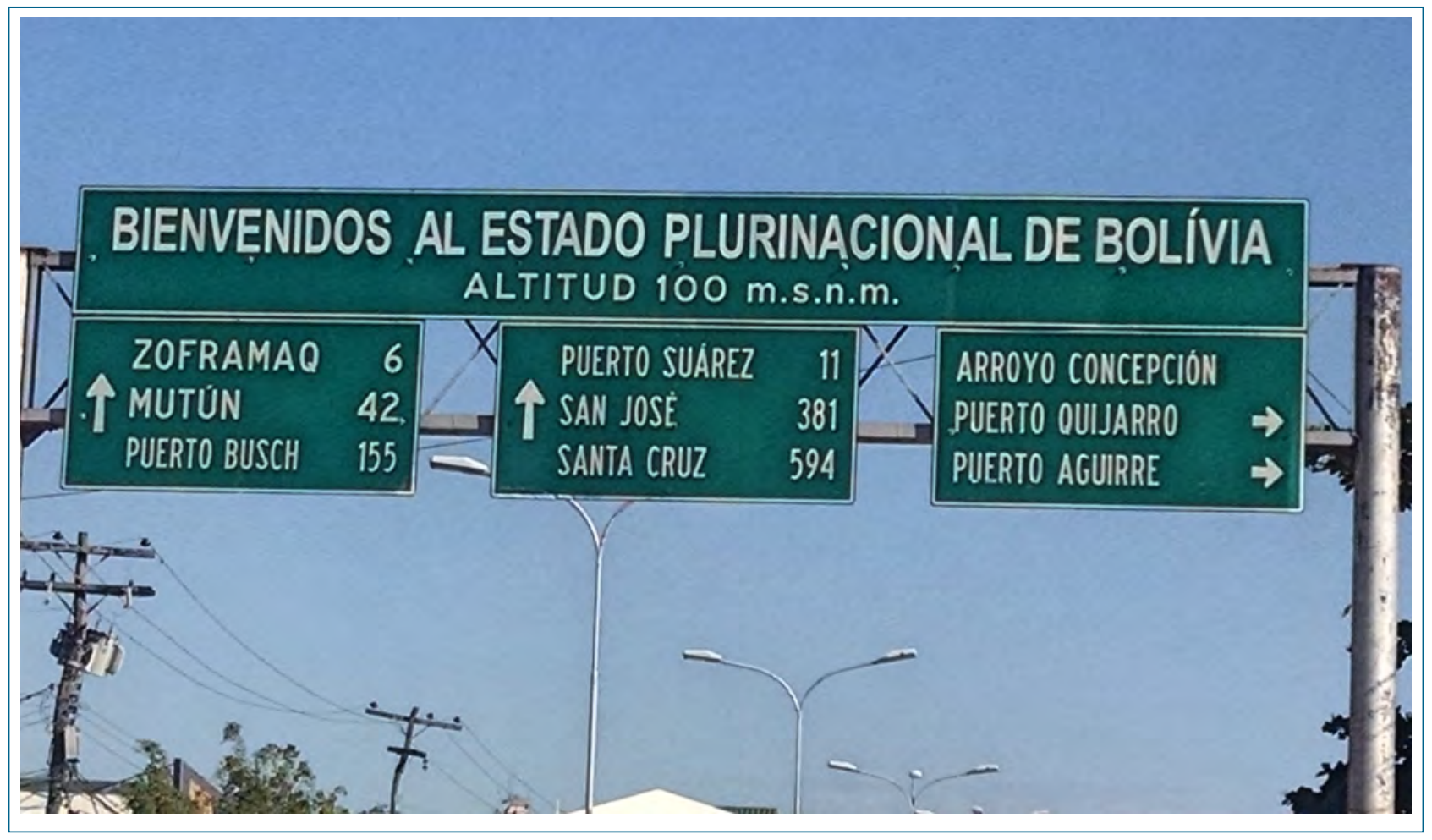

Fotografia: Aldomar A. Rückert, 2015.

Grosso, Rondônia, o Paraguai e a Bolívia, “[...] uma área geopolítica de soldadura caracterizada por seu notório caráter ambivalente amazônicoplatino [...]". (SILVA, 1981, p. 89).

As concepções dos geopolíticos brasileiros, notadamente no período do regime militar (1964-1985) despertaram enorme desconfiança nos países vizinhos, principalmente porque os governos ditatoriais brasileiros estavam comprometidos com ditaduras como as do Paraguai, Bolívia e Chile. Notadamente, a ditadura brasileira procurou exercer o seu papel de potência hegemônica ou sub-imperialista, tendo difundido seus projetos expansionistas investidos de seu destino manifesto ao sul do Caribe, sua política de "expansão pacífica" para o exterior e a teoria de Golbery do Couto e Silva das fronteiras vivas. (SCHILLING, 1981).

No período recente, as negociações da diplomacia econômica do Brasil e dos governos Lula da Silva, de caráter integracionista pós-neoliberal, reservaram à Bolívia um papel estratégico na projeção dos eixos da então denominada IIRSA, qualificando-se o território boliviano como um centro de coesão. O caso boliviano é emblemático, não apenas como um exemplo que ilustra as fortes assimetrias territoriais, mas também por representar um caso de como os projetos do regionalismo aberto e do regionalismo pósneoliberal têm repercutido no território boliviano.

Para autores bolivianos (GUMUCIO; WEISE apud BRUSLÉ, 2005, p. 484), a expansão brasileira rumo ao Centro-Oeste, iniciada no final da década de 1930 e aprofundada durante o regime militar nas décadas de 1970/1980 com a ocupação por agricultores sojicultores e pecuaristas oriundos do sul do país, seria nada mais do que uma marcha em direção à Bolívia. (BRUSLÉ, 2005, p. 482). A opinião pública boliviana é a de que o Brasil é um país ameaçador para os seus vizinhos, denotando um renascimento de um sentimento popular anti-imperialista brasileiro. A participação de empreiteiras brasileiras com financiamentos do BNDES, como OAS e Odebrecht em obras do COSIPLAN ou relacionadas aos eixos de integração provocou fortes reações anti-imperialistas contra 
sua presença no caso da rodovia Villa Tunari - San Ignacio de Mojos.

O conflito da construção da rodovia Villa Tunari - San Ignacio de Mojos que poderá atravessar o Território Indígena e Parque Nacional Isiboro Sécure, TIPNIS, com 1,2 milhão de hectares, localizado nos departamentos de Beni e Cochabamba, é um caso exemplar do sentimento popular anti-imperialista brasileiro e da não aceitação de projetos do COSIPLAN e obras relacionadas pelas populações locais. TIPNIS foi declarado Parque e também Território Indígena em 1965 e 1990, respectivamente, tendo o governo de Evo Morales reconhecido como titulares do território os povos Chimanes, Yuracaré e Mojeño Trinitário, representados pela Sub Central Território Indígena e Parque Nacional Isiboro Sécure. (MARTINEZ, 2013; JIMENEZ, 2011, p. 19).

A rodovia, prevista desde 1826, embora não tenha sido inserida como um projeto do COSIPLAN, foi projetada pela Administradora Boliviana de Carreteras, com 306 quilômetros, para interligar o norte e o centro da Bolívia através do Território Indígena e Parque Nacional Isiboro Sécure. A rodovia, que seria construída pela empresa brasileira OAS, com financiamento do BNDES no valor de 332 milhões de dólares sobre um orçamento total de 415 milhões de dólares, numa aliança política entre os presidentes Lula da Silva e Evo Morales, localizar-se-ia entre os eixos Peru-Bolívia-Brasil, no norte, e o Interoceânico do centro da Bolívia.

A rodovia projetada - motivo de conflitos entre as comunidades indígenas e o governo boliviano - envolveu não apenas os interesses do governo brasileiro para a construção de infraestrutura que viabilizasse a exportação de soja pelos portos do norte do Chile e sul do Peru, mas também interesses de colonizadores, petroleiras e empresas madeireiras. O governo de Evo Morales sustentava que o projeto da rodovia obedecia à decisão de levar desenvolvimento e oportunidades aos indígenas, postergados durante muito tempo. Entretanto, há interesses de mercantilização de terras, a expansão da cultura da coca e o corte ilegal de árvores com madeiras raras; ampliação da fronteira hidrocarbonífera com prospecções na área por empresas estatais, a boliviana YPFB e brasileira Petrobras. (JIMENEZ, 2011, pp. 20-23).

A Confederação dos Povos Indígenas da Bolívia (CIDOB) e outras organizações iniciaram a $8^{\mathrm{a}}$ Marcha Indígena à La Paz, de agosto a outubro de 2011, em oposição ao projeto da rodovia, tendo sido violentamente reprimidas. De acordo com a imprensa local, a pressão popular foi tão intensa que balançou o primeiro governo de um indígena no país. Morales veio a promulgar uma lei que declararia o território de TIPNIS como intangível (Lei Curta 180). (BOLÍVIA, 2011). Seguiram-se os cancelamentos dos contratos com a construtora brasileira OAS e o financiamento de exportação de bens e serviços do BNDES, após denúncias de organizações da sociedade civil junto ao banco sobre diversas irregularidades ambientais e violações de direitos territoriais indígenas. (FONSECA; MOTA, 2013, p. 3; CONECTAS, 2015).

Apesar das concessões de Evo Morales aos movimentos indígenas, as obras da rodovia foram retomadas por empresas bolivianas em 2013 em trechos fora do território TIPNIS. Em 2015, uma unidade de engenheiros militares da Bolívia e da Venezuela deu continuidade às obras em segmentos fora do parque. (CARWIL, 2015). Afirmou Morales sobre a estrada: "Em primeiro lugar ela vai liberar o departamento de Beni. Em segundo lugar haverá uma maior integração entre os departamentos, estamos convencidos disto, trata-se de projetos macro nesta região". (ARIÑEZ, 2015). A retomada das obras passou a ser contestada novamente pela Sub Central dos Povos Indígenas de TIPNIS. Em pronunciamento público as mulheres indígenas rechaçaram de forma categórica a construção da rodovia e a revogação da Lei Curta 180, declarando estado de emergência e mobilização contínua contra a afronta permanente do governo da Bolívia. (PRONUNCIAMENTO, 2017).

O caso da rodovia Villa Tunari - San Ignacio de Mojos evidencia que a implantação de infraestruturas de circulação relacionadas a projetos integracionistas do COSIPLAN não se 
caracteriza por aceitações pacíficas por parte de populações tradicionais, atores civis que, em muitos casos, não são ouvidos. Embora o governo de Evo Morales, mesmo com forte apoio de movimentos sociais indígenas, tenha adotado um enfoque pragmático para procurar conectar regiões periféricas a eixos principais de circulação, a resistência indígena demonstrou que este projeto - e mesmo a pauta da integração sul-americana não faz sentido para os povos tradicionais. Direitos territoriais e ambientais, mesmo em regiões periféricas, não podem ser desrespeitados - esta foi a mensagem que a resistência indígena enviou ao poder do governo boliviano e, por extensão, à UNASUL.

\section{O Corredor Bioceânico Porto Alegre (Brasil) - Coquimbo (Chile) no Eixo MERCOSUL- Chile: interesses empresariais brasileiros, argentinos e chilenos atravessam desertos e serras enquanto demandam nova travessia nos Andes}

O Eixo MERCOSUL-Chile, que apresenta uma malha complexa de infraestrutura, localiza-se no núcleo geoeconômico do MERCOSUL, uma diagonal que se estende do sudeste e sul do Brasil (estados industrializados de Minas Gerais, São Paulo, Paraná, Santa Catarina e Rio Grande do Sul) na macrorregião transfronteiriça da Bacia do Prata, pelo Paraguai e província de Buenos Aires, alongando-se ao centro da Argentina e ao Chile até o Pacífico ${ }^{\mathbf{1 0}}$. A rota que articula o Brasil aos países vizinhos, prolonga-se do sudeste e sul do país a Santiago do Chile através do Passo dos Libertadores (ou Passo Cristo Redentor), entre a Província de Mendoza (AR) e a Província Los Andes

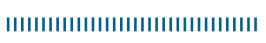

10 O Eixo caracteriza-se por dados superlativos na América do Sul, com $18 \%$ da sua superfície, $34,9 \%$ da população (o eixo mais povoado, com 141.453 .273 habitantes) e $47,7 \%$ do PIB, a maior concentração da riqueza sul-americana (www.iirsa.org). O conjunto de obras do Eixo MERCOSUR-Chile está orientado, dentre outras diretrizes oficiais, a desenvolver a infraestrutura e logística para incrementar o comércio entre os mercados locais, regionais e globais, incrementar a competitividade de cadeias produtivas, o fluxo de bens e serviços, promover o desenvolvimento do turismo, etc. (COSIPLAN, 2016, p. 206).
- IV Região do Chile, está em uso desde 1980 e se caracteriza por intensos fluxos de transportes um importante indicador de transfronteirizações e fluidez territorial - que interligam o mercado brasileiro ao Chile.

O Corredor Bioceânico Central Porto Alegre$\mathrm{BR}$ - Coquimbo $(\mathrm{CH})$ (ver mapas 1 e 2) configura uma linha quase reta de $2.472 \mathrm{~km}$ que interliga a cidade de Porto Alegre, capital do estado do Rio Grande do Sul, extremo sul do Brasil, à cidadeporto de Coquimbo, na Região do mesmo nome no Chile, através das províncias argentinas centrais de Corrientes, Entre Ríos, Santa Fé, Córdoba, La Rioja e San Juan. Encontros entre comitivas de empresários chilenos e do Brasil têm se repetido para tratar dos interesses do empresariado de ambos os países em baratear custos de logística nas exportações para a Ásia e no comércio entre os dois países. (SISTEMA FIERGS, 2015).

O Corredor Bioceânico atravessa a região desértica periférica e semi isolada na região geográfica de Cuyo ${ }^{\mathbf{1 1}}$ (que significa "país de areia") e Serras Pampeanas, onde predomina um clima semi-árido, com marcadas amplitudes térmicas e precipitações pluviométricas de apenas 100 $\mathrm{mm}$ anuais, conjuntos de serras de norte a sul, cordões montanhosos com grandes assimetrias morfológicas, ocupação humana rarefeita em formas de oásis nos contrafortes e nos vales longitudinais que se interpõem entre a grande massa orográfica dos Andes, a Pré-Cordilheira e as serras a leste na diagonal árida sul-americana.

Nesta região desértica periférica de Cuyo estão situados a Ruta Nacional 150 com $389,5 \mathrm{~km}$ e os parques naturais de Ischigualasto (Vale de la Luna) e Talampaya, ambos patrimônio da humanidade da UNESCO. A Ruta Nacional 150 (uma obra da Carteira de Projetos do COSIPLAN, com fundos do tesouro argentino, concluída em 2015) tende

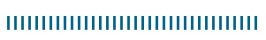

11 A Região de Cuyo é composta por Mendoza, San Juan e São Luis, cujos limites coincidem praticamente com a região geográfica e que compartilham una identidade cultural e tradição histórica em comum. Desde 1988, La Rioja também a compõe, formando a Região de Novo Cuyo. A região de Serras Pampeanas ocupa parte das províncias de Tucumán, Catamarca, La Rioja, Córdoba, San Luis e San Juan. (BALMACEDA, 1997, p. 50; 116; 136). 
Foto 2. Trecho da Ruta Nacional 150, estrada cênica na Serra do Vale Fértil entre o Parque Nacional Talampaya (Província de La Rioja) e San José de Jachal (Província de San Juan).

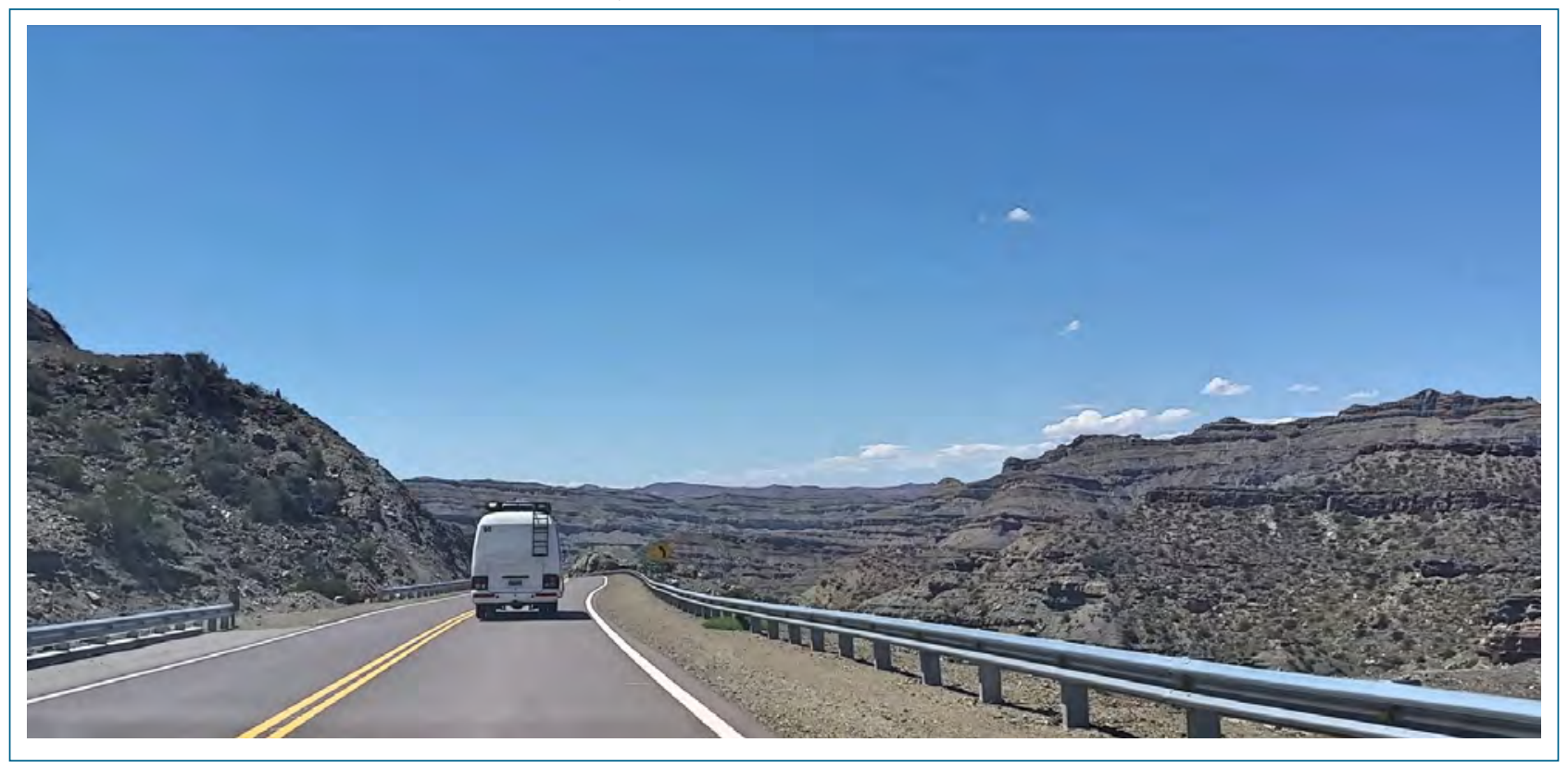

Fotografia: Aldomar A. Rückert, 2017.

a alterar este isolamento, a médio e longo prazo, articulando os fluxos viários entre as regiões do sul do Brasil, o Pampa Argentino, o futuro túnel Água Negra, no passo andino de mesmo nome alternativo ao Túnel Passo dos Libertadores - e a região de Coquimbo no Chile ${ }^{12}$ - o Corredor Bioceânico Porto Alegre (BR) - Coquimbo (CH) (ver mapa 3). Com esta obra monumental estará concluído o novo Corredor que interligará as regiões agrícolas e industriais do sudeste e do sul do Brasil com o Oceano Pacífico, no Chile, encurtando caminhos para a exportação de soja, carne e ferro, por exemplo, para o mercado asiático e para a entrada de automóveis e produtos eletrônicos asiáticos.

A Ruta 150 é uma via cênica que cruza a

|||||||||||||||||||||||||||||||||||||

12 O túnel Água Negra, obra da Agenda de Projetos Prioritários de Integração - API - COSIPLAN, previsto como o segundo túnel a ligar a Argentina com o Chile através dos Andes, é a obra mais significativa do Corredor Central Bioceânico Porto AlegreCoquimbo. Ele será uma passagem alternativa ao Passo dos Libertadores (ou Passo Cristo Redentor), na Província de Mendoza. Orçado em US $\$ 1,6$ bilhões, com financiamentos previstos do BID, a obra que tem atraído dez consórcios com 29 empresas europeias e chinesas. A previsão do anúncio do vencedor do Edital público para executar o túnel de $13 \mathrm{~km}$ com tempo médio entre 8 a 10 anos de trabalhos era para o primeiro trimestre de 2018. (CABALLERO, 2017; BBC Brasil, 2017).
Serra de Vale Fértil (ver foto 2), um sub-sistema das Serras Pampeanas, com seis túneis e com uma engenharia complexa. Por um lado, a via permitirá vincular os núcleos produtivos das regiões argentinas do Pampa Úmido, o Litoral e o Norte Argentino e, futuramente, com o porto de águas profundas de Coquimbo, na IV Região do Chile, possibilitando um novo caminho para o intercâmbio comercial com os países da bacia Ásia-Pacífico (RUTA NACIONAL 150, 2013) além de articular-se com a Ruta Nacional 40, rodovia estrutural que percorre a Argentina de sul a norte, da extrema Patagônia à fronteira com a Bolívia.

Os parques naturais de Talampaya (La Rioja) e Ischigualasto (San Juan) (no total de 278.000 hectares) localizam-se no centro desta região desértica periférica e semi isolada, na Bacia Triássica Ischigualasto, entre a pré-cordilheria dos Andes e as Serras Pampeanas ${ }^{13}$ (ver foto 3). Além da articulação aos eixos viários nacionais

||||||||||||||||||||||||||||||||||||||||

13 Bacias Triássicas: depressões estreitas no oeste da Argentina, alongadas no sentido Noroeste-Sudeste, como a de Ischigualasto - Vila Unión com significativa extensão regional, localizadas entre os terrenos da pré-cordilheira e os rifts das Serras Pampeanas que contêm numerosos restos fósseis que a caracteriza. (RAMOS, 1999; SPALETTI, 1999). 
Políticas territoriais na América do Sul:

infraestruturas de conexão e repercussões em regiões periféricas

Foto 3. Vista dos cordões montanhosos erodidos no Parque Provincial de Ischigualasto / Vale de la Luna (Província de La Rioja), Patrimônio da Humanidade da UNESCO.

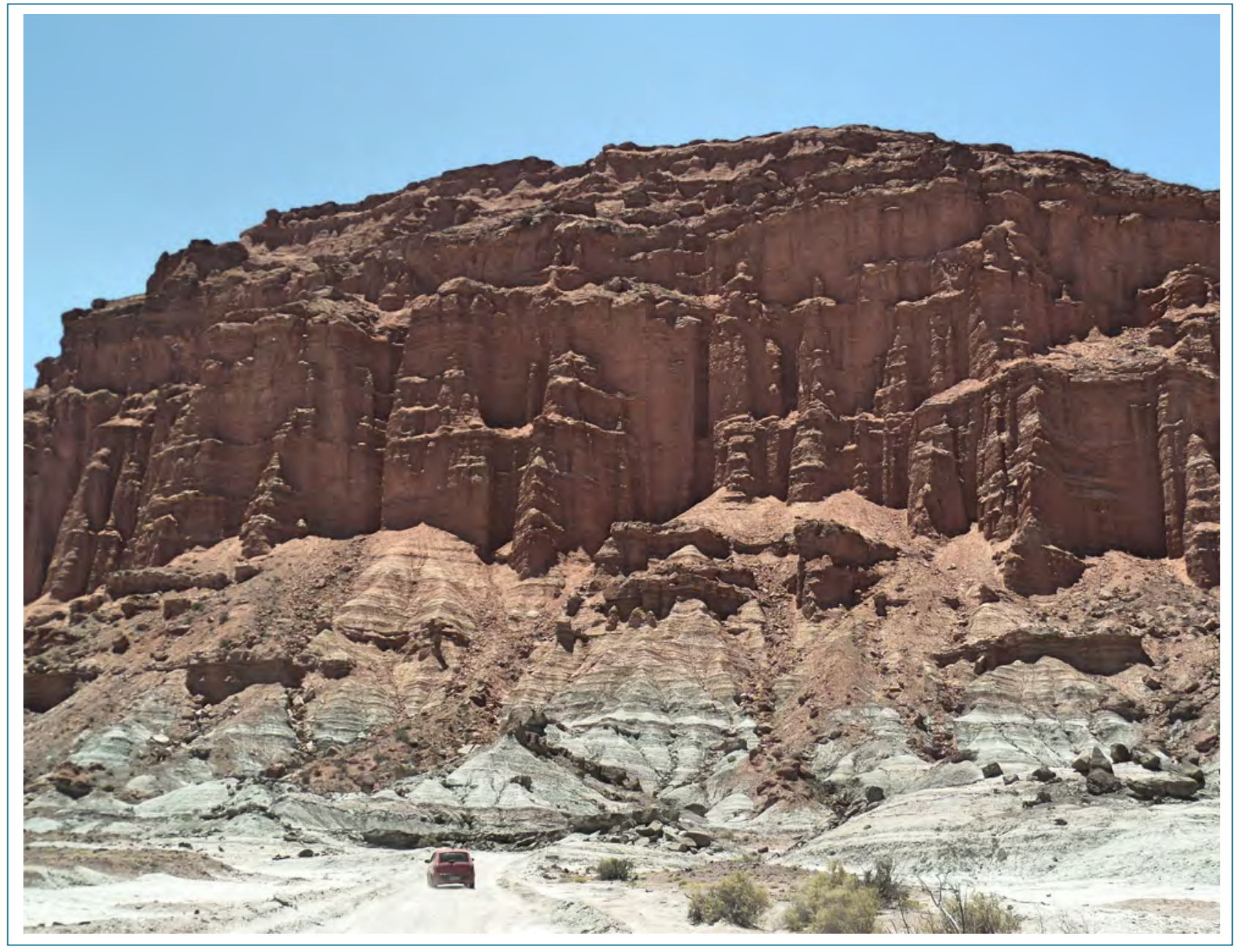

Fotografia: Aldomar A. Rückert, 2017.

Mapa 3. A Ruta Nacional 150, último elo do Corredor Bioceânico Porto Alegre (RS, Brasil) Coquimbo (Chile) e o local do futuro túnel Água Negra.

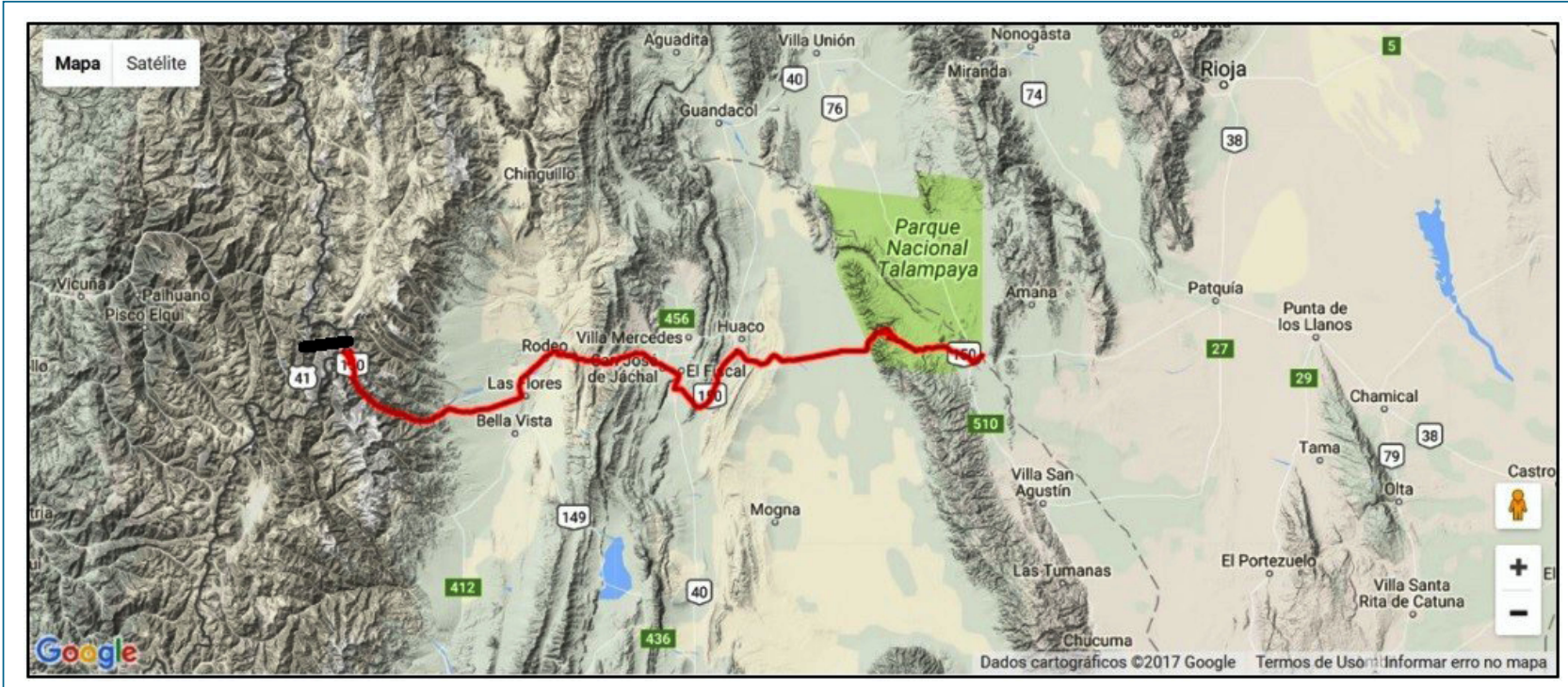

Fonte: <http://www.iirsa.org/proyectos/detalle_proyecto.aspx?h=976> 
argentinos, a Ruta Nacional 150 está tornando possível a integração territorial destes parques naturais, retirando-os do isolamento - eles estão localizados a grandes distâncias dos principais centros urbanos das duas regiões: a $158 \mathrm{~km}$ de La Rioja, $330 \mathrm{~km}$ de San Juan e a $470 \mathrm{~km}$ de Mendoza - e articulando-os aos fluxos comerciais e turísticos.

A Ruta Nacional 150, uma demanda antiga da Província de San Juan, construída com recursos orçamentários do Estado argentino, representa tanto uma combinação de escalas de poder nacional e provincial - na Argentina quanto uma articulação política dos interesses dos empresariados brasileiro, argentino e chileno com a escala sul-americana representada pela UNASUL através do projeto do Corredor Bioceânico. O corredor é uma conjugação de interesses destes empresariados, embora ainda não concluído, pois ele somente estará completo com a construção do túnel Água Negra - que tem suas obras estimadas em um tempo médio de dez anos. Em médio e longo prazos pode-se prever que venha a existir uma relativa abertura da região periférica de Cuyo e Sierras Pampeanas aos fluxos comerciais e turísticos argentinos, brasileiros e chilenos.

É de supor-se que a dinamização do turismo ambiental e paleontológico venha ampliar o valor econômico e imaterial dos parques naturais de Ischigualasto e Talampaya à medida que os fluxos comerciais venham aumentar através do Corredor Bioceânico Central Porto Alegre$\mathrm{BR}$ - Coquimbo- $\mathrm{CH}$, quando este estiver em funcionamento pleno. O aumento dos fluxos rodoviários turísticos através da Ruta 150 já é visível com o grande número de visitantes que chegam aos parques. Enquanto isto, esta região desértica periférica semi isolada, com parques de grande beleza cênica, ainda é desconhecida do grande público de turismo. "Mesmo os argentinos pouco conhecem esta pedra preciosa do turismo nacional" (QUATRO CANTOS), ou como consta em um blog brasileiro de explorações geográficas a respeito de Talampaya: "Não, você não conhece e você nunca deve ter ouvido falar”. (LISBOA, s.d.).

\section{O Eixo das Guianas no Escudo das Guianas e suas infraestruturas precárias}

O Escudo das Guianas ${ }^{14}$ corresponde a uma região periférica dentro da Amazônia. Parte desse isolamento se explica pela estratégia do governo brasileiro de manter a região Norte do país relativamente desprovida de conexões terrestres. Corroborando esse entendimento, Porto (2010, p. 139) entende que a Amazônia segue sendo tratada como periférica pelo governo federal do Brasil, bem como pelas elites locais. No Escudo das Guianas processos de transfronteirização encontram-se em estágios embrionários, tendo em vista os vastos espaços ocupados por florestas, as grandes distâncias entre as cidades e povoados e o pequeno volume de circulação de mercadorias e pessoas pelo interior amazônico, restritos quase que ao movimento de mineradores, via de regra ilegais.

Cabe destacar que, até o presente, apenas três rodovias (BR-156, BR-174 e BR-401) conectam a área correspondente à calha norte do rio Amazonas aos países vizinhos. A ausência de infraestruturas de transporte terrestre e a presença de grandes áreas de preservação (parques nacionais, terras indígenas, etc.) são fatores que dificultam enormemente o trânsito de pessoas e mercadorias na região, mas que, ao mesmo tempo, servem de defesa contra uma eventual invasão por parte de um país inimigo. De acordo com o Programa de Desenvolvimento da Faixa de Fronteira, “[...] o reconhecimento das terras indígenas e a criação de unidades de conservação atuam no sentido de estabilizar o povoamento e dificultar a entrada de frentes pioneiras internas e externas". (BRASIL, 2009, p. 35).

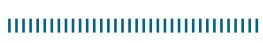

14 O Escudo das Guianas, também denominado Planalto das Guianas, é formado pela grande massa de escudos ao norte do rio Amazonas e a leste do rio Orinoco e abrange áreas da Venezuela (31.304.016 hab.), Guiana (737.718 hab.), Suriname (591.919 hab.), Guiana Francesa (252.338 hab.) e dos estados brasileiros de Amapá (797.722 hab.), Roraima (522.636 hab.) e Amazonas (4.063.614 hab.). Também fazem parte pequenas áreas do estado brasileiro do Pará (8.366.628 hab.) e da Colômbia (47.698.524 hab.). (Fontes: IBGE; CIA, 2017). 
A preocupação com a defesa se explica pela história de colonização da Amazônia setentrional, que foi marcada por uma disputa entre potências europeias que resultou na constituição das três Guianas - neerlandesa, francesa e britânica. Os neerlandeses começaram a colonizar as áreas costeiras entre os rios Orinoco e o Amazonas a partir do século XVII (fundação das colônias de Essequibo em 1614, Berbice em 1627 e Suriname em 1667). Em 1643, os franceses fundaram Caiena. Posteriormente, em 1796, os britânicos se estabeleceriam na região, tomando áreas dos Países Baixos, que viriam a formar a Guiana britânica em 1831.

A preocupação com a defesa acompanhou desde o início a história de colonização da Amazônia brasileira. Os portugueses, após destruírem os fortes neerlandeses e ingleses na Bacia Amazônica entre o final do século XVI e o início do século XVII, passaram a construir fortificações na região. Como exemplos, podem ser citados: a fortaleza de São José da Barra do Rio Negro, construída em 1670, nas proximidades da atual cidade de Manaus; o forte São Joaquim, erguido em 1778, no atual estado de Roraima; e a fortaleza de São José de Macapá, construído em 1782, entre outros. (BARRETTO, 2010).

No que tange à colonização da Amazônia setentrional brasileira, Burgardt (2012) destaca que no século XVIII os portugueses implantaram na área que corresponde ao atual território de Roraima uma economia baseada na pecuária bovina e apenas no início do século XX os garimpeiros brasileiros passariam a ocupar áreas indígenas no Escudo das Guianas. Por sua vez, do outro lado da fronteira, a Guiana venezuelana foi a última região daquele país a ser controlada pelo colonizador europeu, fato que remonta ao segundo terço do século XVIII. Contudo, somente a partir da década de 1970, com os recursos do petróleo, Caracas passou a promover grandes projetos hidroelétricos e industriais para a Guiana venezuelana.

A história de povoamento explica a condição periférica do Escudo das Guianas. Uma região que não abrange as grandes cidades amazônicas, como Manaus ou Belém, e que fica distante dos principais polos econômicos da América do Sul. Além disso, o Escudo das Guianas se distingue das demais áreas do subcontinente pela influência das antigas metrópoles europeias (França, Países Baixos e Reino Unido).

No que tange à Guiana Francesa, Silva (2014) destaca que apesar de se tratar de um departamento ultramarino francês, em função de seu isolamento, concentração demográfica (a população ocupa essencialmente o litoral) e da forte dependência em relação à França metropolitana, o território apresenta problemas e deficiências semelhantes aos dos países sul-americanos. Apesar dos recursos obtidos em virtude do Centro Espacial de Korou, as taxas de desemprego são altas e é grande o peso do setor primário na economia (pesca e madeira). Por conta disso, a Guiana Francesa é considerada uma região ultra-periférica da União Europeia e dispõe de políticas específicas a seu favor, sendo contemplada pelo programa destinando a fomentar o desenvolvimento de regiões fronteiriças e remotas - o INTERREG.

Em relação ao Suriname, Oliveira (2013) destaca que o país, desde a década de 1980, vivencia um fluxo sem precedentes de garimpeiros brasileiros para o seu território. O país, cuja economia é dependente da exportação de bens primários (ouro, bauxita, petróleo bruto e banana), possui uma população imigrante ilegal que é responsável por grande parte da extração aurífera, uma das principais atividades econômicas do país.

Por sua vez, a República Cooperativa da Guiana, país mais pobre da América do Sul, com uma economia pautada na produção de bens primários (ouro, bauxita, arroz e açúcar), vive um clima de tensão geopolítica com a Venezuela em virtude da disputa pela região do Essequibo. A questão, que remonta ao século XIX, foi acirrada nos últimos anos pela descoberta de imensas jazidas de petróleo na plataforma continental guianense e pelo fato de o governo do país ter outorgado licenças de exploração a grandes multinacionais petrolíferas. A disputa tem gerado entraves no aprofundamento da integração regional e vem sendo impactada e manipulada em função da grave crise políticoeconômica vivida pela Venezuela desde 2013. 
Mapa 4. Eixo do Escudo das Guianas no Brasil, Guiana Francesa, Suriname, Guiana e Venezuela.

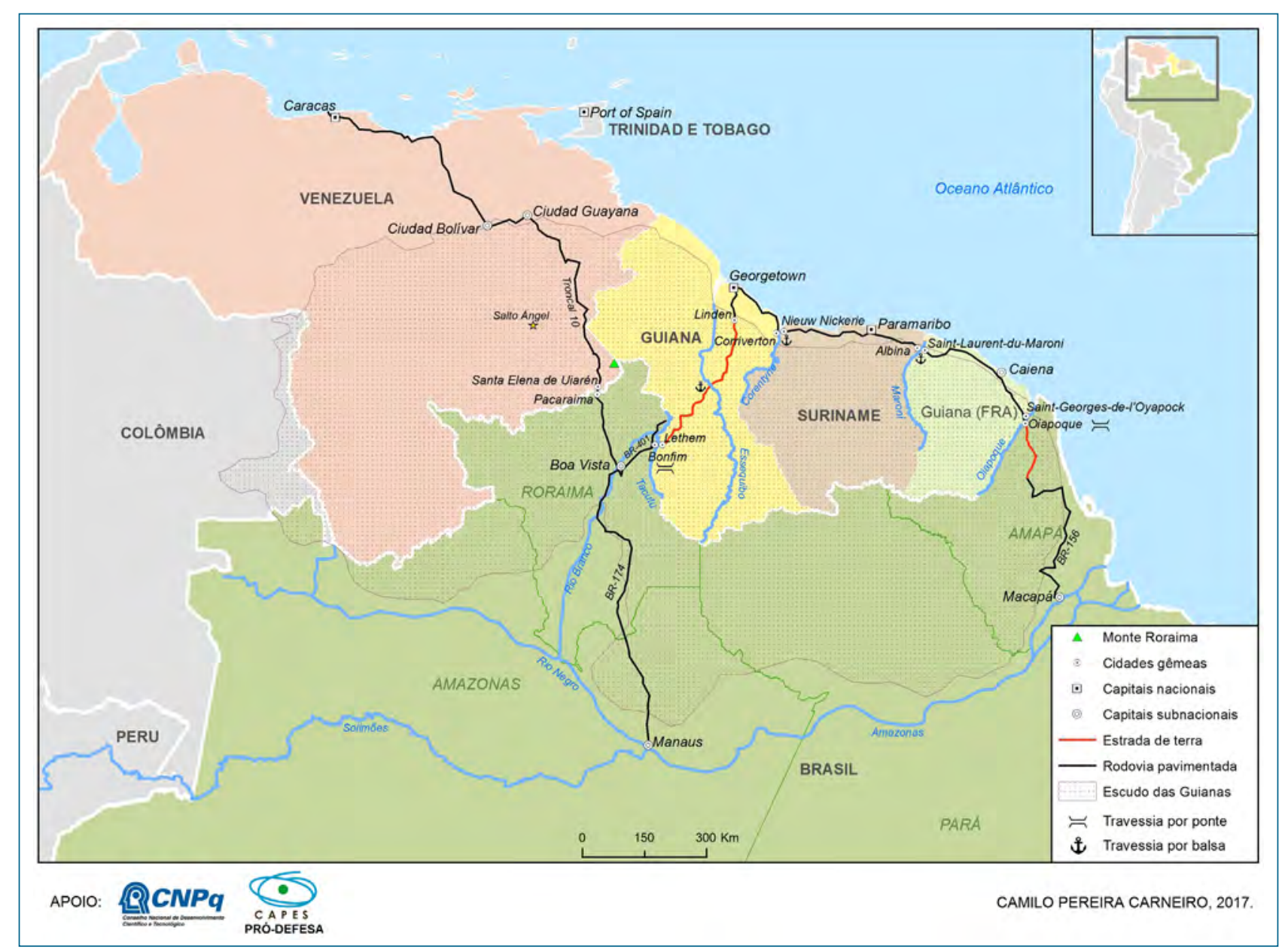

Apesar do contexto geopolítico pouco favorável e da pequena importância econômica (que poderia ser completamente alterada em caso de um aumento significativo dos preços do petróleo no mercado internacional), ainda existem projetos do COSIPLAN para o eixo do Escudo das Guianas. A quase totalidade desses contempla obras do setor de transportes ${ }^{15}$, merecendo destaque

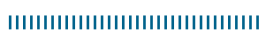

15 A Carteira de Projetos do COSIPLAN aponta quatro grupos de projetos do Escudo das Guianas: interconexões Venezuela-Brasil, Brasil-Guiana, Venezuela (Cidade Guiana) - Guiana (Georgetown) - Suriname (Paramaribo) e Guiana-Suriname-Guiana FrancesaBrasil. No total de vinte projetos agrupados nestes quatro grupos somente a reabilitação da rodovia Caracas-Manaus encontra-se em fase de execução, com previsão de término até 2019. A ponte internacional sobre o rio Oiapoque (Brasil-Guiana Francesa) e linhas de fibra ótica conectando Caracas ao norte do Brasil são dois dos poucos projetos concluídos. (COSIPLAN, 2016, p. 147). um conjunto de pontes e rodovias que juntos formariam a rodovia Transguianense, conforme demonstra o mapa 4, acima.

O Eixo do Escudo das Guianas se caracteriza pela grande população de garimpeiros que atuam de forma informal e mesmo ilegal, transitando pelas fronteiras de cinco países sem a documentação adequada. Nesse sentido, os projetos do COSIPLAN podem ser relacionados com um possível aumento do fluxo migratório. A questão é problemática, sobretudo, na Guiana Francesa, onde a atuação de cerca de 20 mil garimpeiros originários do norte do Brasil é combatida pelas forças de segurança francesas, tendo chegado a resultar na implementação, por parte da França, de um visto exigido aos cidadãos brasileiros que desejam viajar para o território ultramarino francês. (PEREIRA CARNEIRO, 2015). 
Apesar dos esforços do Ministério de Relações Exteriores, que atende os brasileiros detidos nas penitenciárias da Guiana Francesa, o desconhecimento da realidade amazônica por parte das autoridades de Brasília é um problema que tem impactado negativamente a região ao longo dos anos. Além disso, percebe-se uma falta de diálogo entre o governo federal do Brasil e as populações das cidades amazônicas que recebem as obras do COSIPLAN. A tardia inauguração da ponte sobre o rio Tacutu (entre Bonfim, RoraimaBrasil e Lethem, Guiana), em 2009, e o atraso de mais de 6 anos na abertura da ponte internacional Amapá-Guiana Francesa - concluída em 2011 e aberta em 2017 - são alguns exemplos.

A rodovia BR-156, no Estado do Amapá, obra federal do Brasil mais antiga ainda em andamento, teve início na década de 1940, e que em 2017 ainda possuía um trecho de pouco mais de 100 km sem pavimentação. Desde 2000, as obras da IIRSA-COSIPLAN vinham sendo executadas pelas grandes empreiteiras brasileiras que contavam com o financiamento do BNDES. A partir de 2014, essas empreiteiras foram impactadas pela Operação Lava Jato, da Polícia Federal do Brasil, que revelou esquemas de corrupção em licitações e de desvio de verbas públicas dos quais faziam parte as maiores empreiteiras do Brasil.

Uma vez retomados os investimentos nas obras da IIRSA-COSIPLAN para o Escudo das Guianas, a região poderia sentir os impactos da conexão entre espaços com baixas densidades de capital, baixa densidade populacional e de meios técnicos, além de pouca fluidez na circulação. Na foto 4, vê-se as embarcações que fazem a travessia do rio Maroni, entre as localidades de Saint-Laurent-du-Maroni, na Guiana Francesa, e Albina no Suriname. Apesar de existir um grande número de embarcações que fazem a travessia de veículos e pedestres, as aduanas dos dois lados da fronteira possuem horários de funcionamentos específicos, fechando em determinados períodos do dia, o que limita o trânsito de pessoas entre os dois lados. Além disso, a França exige visto de entrada a cidadãos surinameses e brasileiros que desejam adentrar o território da Guiana Francesa.

No trajeto entre Georgetown, a capital da República Cooperativa da Guiana, e a cidade de
Lethem, na fronteira com o Brasil, grande parte da rodovia não é asfaltada (ver foto 5). Além disso, a viagem é dificultada pelos poucos horários de funcionamento da balsa que faz a travessia do rio Essequibo, o que ocorre apenas duas vezes ao dia (a cada 12 horas). O percurso, que no período seco dura em média 24 horas, em função das condições da estrada, é realizado por meio de vans, que transportam em seu interior, junto com os passageiros, mercadorias de todo tipo (material de construção, alimentos e até galões de gasolina), o que torna a viagem muito perigosa, desconfortável e cansativa.

Além das obras futuras previstas, cabe destacar a necessidade da homogeneização das diferentes legislações entre os países. A União Europeia, por exemplo, não permite a circulação de veículos que poluam mais do que o estabelecido pelas normas do Regulamento (CE) n. ${ }^{\circ} 715 / 2007^{16}$. Ainda que a questão das divergências entre as legislações venha a ser dirimida, é importante ressaltar que a retomada dos projetos de infraestrutura no Escudo das Guianas poderia gerar impactos positivos, mas também negativos. De um lado, as obras de conexão viária serviriam como fator impulsionador do turismo ecológico nos parques nacionais do Escudo das Guianas, que tem no Monte Roraima (tríplice fronteira BrasilVenezuela-Guiana) e no Salto Ángel (Venezuela), seus grandes atrativos. Contudo, a facilidade de movimentação também poderia trazer impactos negativos ao potencializar atividades criminosas, facilitando a entrada de garimpeiros clandestinos e o comércio e transporte de drogas na região.

\section{Rumos atuais da integração sul-americana: da proposta da América do Sul como uma região geopolítica e das infraestruturas como articuladores territoriais à crise da UNASUL}

Neste último tópico apresentam-se considerações sobre os rumos atuais da integração sul-americana e das infraestruturas de conexão, cenário onde

IIIIIIIIIIIIIIIIIIIIIIIIIIIIIIIII

16 Regulamento (CE) n. ${ }^{\circ}$ 715/2007, relativo à homologação dos veículos a motor no que respeita às emissões dos veículos ligeiros de passageiros e comerciais (Euro 5 e Euro 6). 
Foto 4. Embarcações no porto de Saint-Lauren-du-Maroni (Guiana Francesa), rio Maroni, fronteira Guiana Francesa-Suriname.

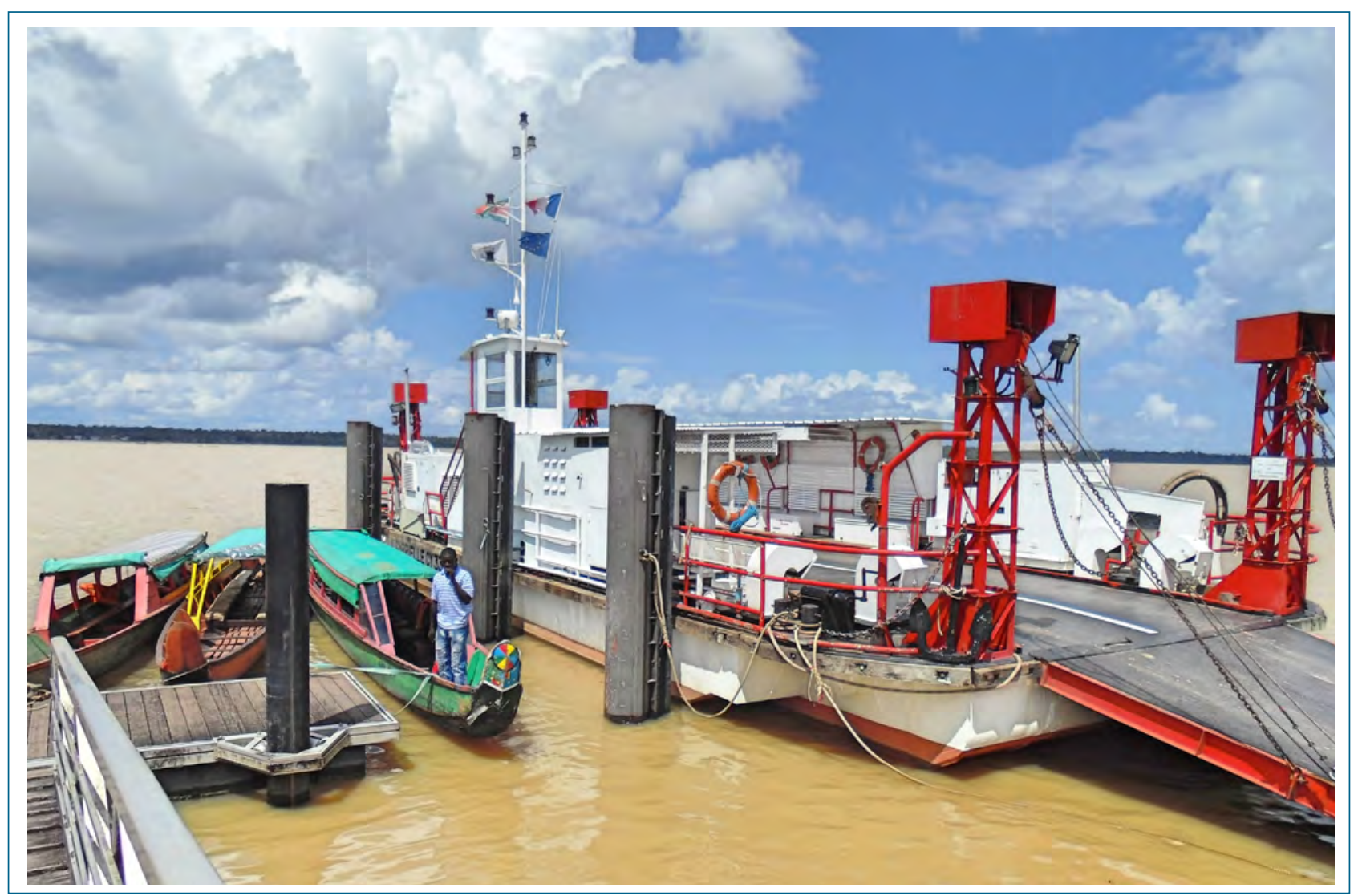

Fotografia: Camilo Pereira Carneiro, 2013.

Foto 5. Barreira de fiscalização da polícia guianense na rodovia Georgetown - Lethem (Guiana) - Bonfim (Roraima, Brasil).

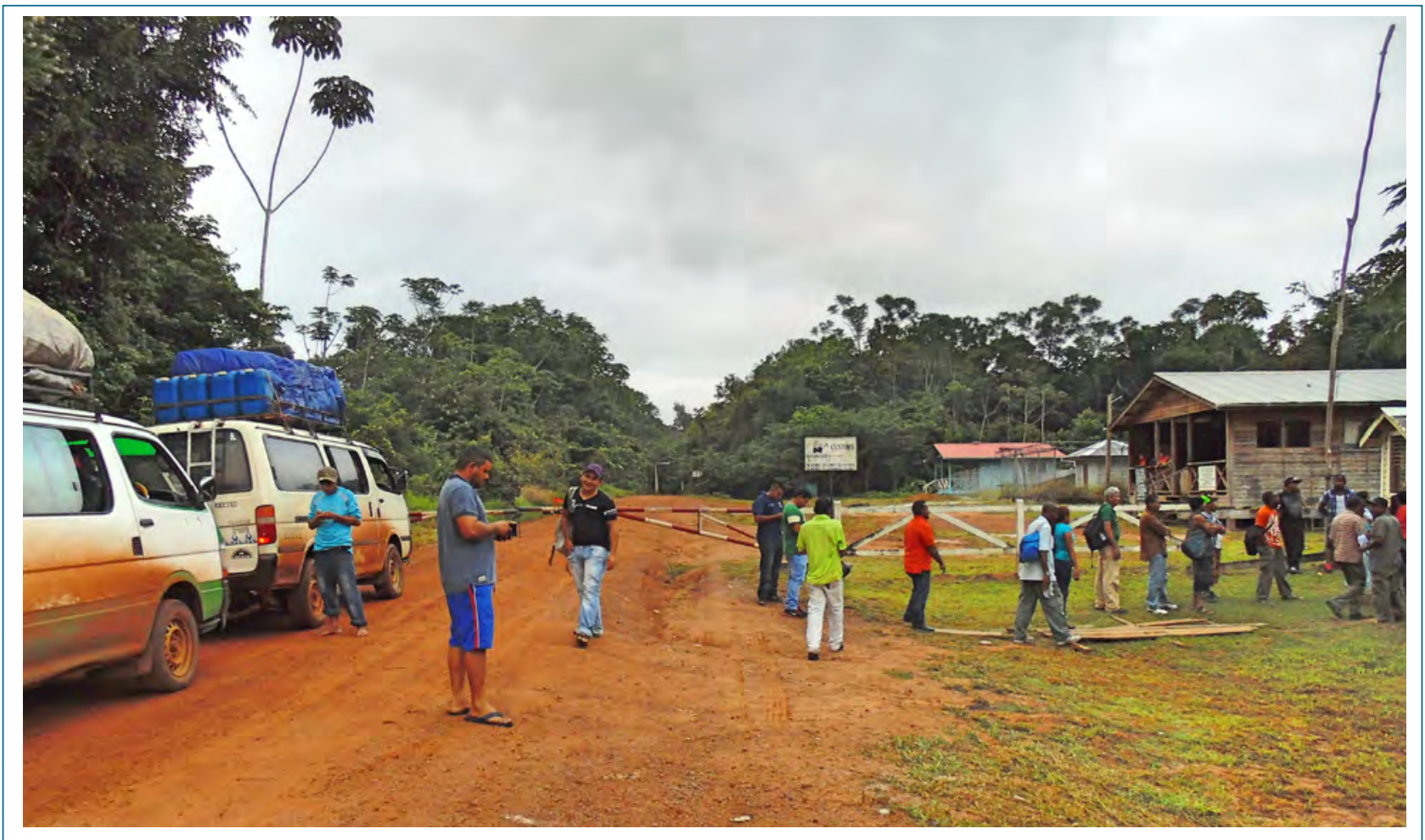

Fotografia: Camilo Pereira Carneiro, 2013. 
há, atualmente, uma verdadeira ausência de continuidade do ideário da América do Sul como uma região geopolítica. Pode-se mesmo afirmar que ela é pouco visível na UNASUL e nas tendências políticas de governos que têm feito opções por medidas ortodoxas de contenção de investimentos e voltadas para o mercado por vias privatizantes.

Vários projetos de integração política, econômica e de infraestruturas de articulação viária e energética encontram-se fortemente condicionados à crise mundial pós-2008, mais notadamente a partir dos anos 2011-2012. Os anos dourados das economias exportadoras ${ }^{17} \mathrm{e}$ dos avanços da integração sul-americana chegam ao fim com o ambiente recessivo da economia mundial, a morte de Hugo Chávez, em 2013, e a crise política em que se encontra a Venezuela, com sua atual suspensão do MERCOSUL, a retomada de programas neoliberais por governos que se sucedem pós-2015 na Argentina, com a eleição de Maurício Macri e a deposição por meio de golpe parlamentar de Dilma Rousseff no Brasil, principalmente.

Estudo recente da organização Global South demonstra que a economia mundial ainda não se recuperou dos efeitos da crise financeira que iniciou há quase uma década atrás. "Apesar da recente recuperação cíclica o crescimento da renda global permanece abaixo dos níveis registrados antes da crise". (AKYÜZ; YU III, 2017, p. 1). O cenário econômico não está muito melhor no Sul Global, diz o estudo. A crise moveu-se numa terceira onda para várias economias emergentes após haver-se movido dos Estados Unidos para a Europa. As principais economias emergentes que eram esperadas, alguns anos atrás, tornar-se locomotivas globais (BRICS: Brasil, Rússia, Índia, China e África do Sul) agora são vistas como parte do problema, gerando impulsos deflacionários

||IIIIIIIIIIIIIIIIIIIIIIIIIIIIIIIIII

17 No período de 2000 a 2007 o crescimento do comércio mundial de bens e serviços foi de $68 \%$. A taxa de crescimento médio da China no período foi de 10,5\%, Índia, 6,8\% e Brasil, 3,7\% contra apenas 2,6\% dos países desenvolvidos. O período de 2004 a 2007 havia sido ainda mais favorável: 9,2\% de crescimento da Índia; $6 \%$ do Brasil em 2007 e, sobretudo, para a China, 14,2\% naquele ano. (CONDE, 2017, p. 3-4). para a economia mundial. Como afirma Conde (2017, p. 17) China e Índia enfrentam dificuldades concernentes a suas taxas de crescimento e o Brasil está em colapso, onde agitações violentas têm acontecido, com a população exigindo mudanças dos rumos econômicos e políticos.

O governo de Michel Temer, então vicepresidente de Dilma Rousseff (2011-2016) que a sucedeu através de um golpe parlamentar a partir de maio de 2016, mudou as diretrizes políticas eleitas democraticamente em 2014: de linhas desenvolvimentistas com ampla inserção social e redistribuição de renda optou-se pela associação com os grandes bancos e indústrias promovendo programas neoliberais e privatistas com reformas econômicas recessivas. O economista José Serra, um dos políticos que conspiraram contra o governo de Rousseff, de orientação político-ideológica neoliberal, ao assumir como Ministro das Relações Exteriores em 2016 (demitiu-se em 2017) mudou a agenda diplomática do Brasil para a América do Sul. Além de severo crítico dos governos populares no país e nos países vizinhos (mudando o princípio da não intervenção nos assuntos internos de outros Estados), as ações ministeriais voltaramse contra o projeto do Brasil aspirar a um assento permanente no Conselho de Segurança da ONU; a própria participação brasileira e da Venezuela no MERCOSUL, tendo agido para suspender o país por tempo indeterminado, alegando descumprimento de obrigações de tratados e normas técnicas. (SPEKTOR, 2017). Além disso, mudou-se a prioridade da política brasileira de diversificar as relações do Brasil com todos os Estados e, finalmente, com a tentativa de alinhar o país com a política externa norte-americana em todos os temas, sem colocar acima de tudo os interesses brasileiros. (LÍRIO, 2017).

A ausência atual da política externa na América do Sul indica de que o Brasil não possui mais um projeto de desenvolvimento para a região. A recente decisão do Brasil e mais cinco países (Argentina, Paraguai, Colômbia, Chile e Peru) de suspender sua participação na Unasul (ISTOÉ, 2018) corrobora a tendência de inexistência, ao menos do Brasil, de uma política externa para a 
América do Sul. Ao mesmo tempo evidenciamse processos concomitantes: o avanço da China com investimentos sobre a América do Sul; a ausência brasileira na mediação do processo de paz na Colômbia; a redução do espaço de atuação da diplomacia brasileira na América do Sul, visto que Suriname, Guiana, Bolívia, Equador e Venezuela (quase a metade da América do Sul) são, hoje, estranhos à política externa do país; o avanço gradual dos EUA com sua influência sobre o Paraguai, Suriname, Colômbia e Argentina com cooperações ou a presença de bases militares, tornando a região uma arena de disputas comerciais e políticas com a China, enquanto que a Aliança do Pacífico - Colômbia, Peru, Chile e México - se fortalece. (KALOUT, 2017). Além disso, estes países deram os primeiros passos rumo à criação de um fundo comum para financiamento de infraestrutura, além de passar a contar com Canadá, Austrália, Nova Zelândia e Cingapura em acordos que contemplam a livre circulação de bens e serviços, além de facilidades para a mobilidade dos cidadãos. (MANETTO, 2017).

Neste contexto de incertezas sobre os rumos políticos da UNASUL, vozes de oposição criticamna, afirmando que a organização perdeu sua razão de ser, devendo-se acabar com ela de uma forma ordenada "o mais rapidamente possível”. (MONTOYA, 2017). A atuação antihegemônica aos interesses dos EUA dos governos de esquerda na região nos anos 2000, além de projetos extra-regionais como os BRICS, enfrenta uma contrarreação com a definição do Atlântico Sul como espaço estratégico de relevância crescente para os EUA no contexto de iniciativas para conter o poder sino-indianobrasileiro na América do Sul e África, além de projetos de consolidação de zonas de influência: o pivô asiático (Parceria Transpacífico) e o pivô Transatlântico. (PECEQUILLO, 2016).

Analisando-se os resultados obtidos pela então denominada IIRSA ao final dos anos 2000, Padula (2014) afirma que as ações governamentais haviam se concentrado em pequenos projetos de transporte e deixando de lado a possibilidade de levar à frente projetos estruturantes, havendo o próprio BID emitido parecer neste sentido. Afirma o Relatório do BID, reconhecendo o surgimento do empoderamento dos países sul-americanos em meados dos anos 2000, que os esforços realizados pelo COSIPLAN não haviam sido suficientes para melhorar os índices de qualidade e disponibilidade de infraestrutura e nem para conseguir uma melhora na competitividade da região sulamericana. "Por um lado, a posição da região na ordem mundial de qualidade da infraestrutura tem piorado e por outro, a lacuna entre o volume de comércio externo e o stock de infraestruturas de integração tem-se ampliado". (BID, 2008). No mesmo sentido de críticas ao COSIPLAN, estudo da Confederação Nacional da Indústria - CNI - aponta que a queda da participação da região no comércio exterior brasileiro nos dois últimos decênios deve-se, entre outros fatores, à má qualidade da infraestrutura. (CONFEDERAÇÃO, 2015).

Em que pesem as críticas ao aos projetos da IIRSA-COSIPLAN, há estudos que apontam crescimento do comércio internacional após 2011 com a conclusão de rodovias internacionais como a Rodovia do Pacífico, já mencionada. Embora o comércio entre os dois países continue mais expressivo pelos transportes aéreo e marítimo, houve aumento de $3 \%$ nas exportações brasileiras e $5 \%$ nas peruanas somente através deste modal rodoviário. (INTEROCEÂNICA, 2017).

As críticas aos governos que criaram a UNASUL, as instabilidades políticas na região e as denúncias de corrupção de ex-autoridades governamentais trazem novos complicadores para o futuro da organização. As denúncias e processos tem-se estendido a vários países, dentre eles Equador, Peru, Argentina, México, República Dominicana, Panamá, Colômbia e Venezuela (BARROCAL, 2017; BENITES, 2017). No Peru, o fim da participação da empreiteira brasileira Odebrecht em dois projetos de infraestrutura - a Rodovia do Pacífico e a represa Chavinomochia III - e as acusações contra ex-presidentes e ex-ministros levaram o ex- presidente Kuczynski a afirmar que não havia como negar que o caso Odebrecht "é um freio para a economia." (FOWKS, 2017). A recente prisão do ex-presidente Ollanta Humala, 
acusado de lavagem de dinheiro em doações feitas pelo grupo brasileiro Odebrecht em suas campanhas presidenciais de 2006 e 2011 (Humala exerceu o mandato entre julho de 2011 e julho de 2016) (TOLA, 2017) confirma o cenário de complicações políticas e jurídicas para os projetos de integração da infraestrutura sul-americana, ao menos no que diz respeito à participação de empreiteiras brasileiras em projetos da carteira do COSIPLAN. Já Kuczynski renunciou ao governo do Peru no fim do mês de março de 2018 para não ser cassado pelo Congresso peruano devido aos envolvimentos em corrupções com a construtora brasileira Odebrecht.

Em consonância com a retomada do alinhamento do Brasil com a política externa norte-americana, o atual governo brasileiro está novamente em negociação, após Lula cancelar a proposta do governo anterior de Fernando $\mathrm{H}$. Cardoso, para ceder o usufruto da base militar de Alcântara (no estado do Maranhão) para o governo norte-americano lançar satélites, com riscos de que a área venha a ser utilizada para o lançamento de ogivas nucleares. Além disto, o governo brasileiro firmou, em março de 2017, acordo de parceria tecnológica com os EUA a título de incentivo da indústria nacional de defesa. O acordo, diz a nota da agência de notícias financeiras Bloomberg, é o "último sinal duma mudança na política externa na maior economia da América Latina após o fim de mais de uma década de governos de esquerda com o impeachment da Presidente Dilma Rousseff”. (ADGHIRNI, 2017). Em de novembro de 2017 ocorreu a Operação Amazon Log Brasil e Estados Unidos na tríplice fronteira entre Peru, Brasil e Colômbia. O exército dos EUA teria participado do exercício militar multinacional de simulação de ações de ajuda humanitária, segundo o general Guilherme Cals Theophilo Gaspar de Oliveira, comandante logístico do Exército brasileiro. (NASCIMENTO, 2017). Em contraposição, a ala nacionalista do Exército brasileiro considerou a presença dos norte-americanos na região estratégica da tríplice fronteira um crime de lesa-pátria. (MELO, 2017).

Neste cenário de crise e incertezas na América do Sul é sintomática a recente publicação do
Banco Mundial anunciando a renovação do regionalismo aberto, opção neoliberal dos anos 90, com propostas para toda a América Latina, enfatizando que os ganhos potenciais de toda a região podem ser atingidos combinando-se reformas estruturais e futuras liberalizações do comércio com o resto do mundo. (BOWN et alii, 2017). Diz o estudo que ainda há espaço para mais acordos preferenciais especialmente entre América do Sul, Central e a América do Norte. Evidencia-se que o Banco Mundial volta a ocupar espaço como conselheiro de governos que se sucedem aos progressistas dos anos 2000 com opções preferenciais por privatizações, medidas econômicas ortodoxas e alianças com o poder hegemônico norte-americano. O banco volta a sugerir medidas já experimentadas na América Latina na década de 1990, que redundaram em aprofundamento das crises econômicas e recessões com altíssimos custos sociais. A América do Sul está frente a uma encruzilhada com prenúncios de graves retrocessos políticos que tenderão a perpetuar seus problemas crônicos.

\section{Algumas conclusões}

Abordar políticas territoriais em processos de integração na escala sul-americana constitui-se num grande desafio para a Geografia Política. A região-continente ou região geopolítica América do Sul apresenta grandes assimetrias internas, o que dificulta, sobremaneira, as observações, a análise territorial e as previsões de possíveis transformações. Possíveis relações entre políticas públicas e suas repercussões territoriais configuram uma questão de investigação ainda relativamente recente no cenário sul-americano, muito embora haja vários esforços para se compreender os processos de integração das infraestruturas da IIRSA-COSIPLAN. A começar pela dificuldade da ausência de uniformidade de dados secundários publicados pelas agências estatais de estatísticas, a análise territorial encontra ainda pouco respaldo na literatura especializada, salvo os estudos com abordagens regionais focados em escalas subnacionais e/ou, eventualmente, transfronteiriças. 
O desafio da análise territorial em escala supra nacional sul-americana implica numa visão de conjunto da região-continente, com a utilização de dados nacionais (ainda não uniformes entre os Estados) e de cartografias temáticas que possam demonstrar tanto algumas homogeneidades e heterogeneidades como as profundas assimetrias e fraturas territoriais.

A perspectiva dos regionalismos recebeu na América do Sul nos anos 2000, inegavelmente, um conjunto de políticas progressistas que ampliaram e aprofundaram os objetivos do velho regionalismo e do regionalismo aberto. O projeto da América do Sul como uma região geopolítica na escala macro da UNASUL introduziu, provavelmente, após o fim da Guerra Fria, pela primeira vez no subcontinente, não apenas o resgate dos ideais integracionistas do século XIX, mas também uma verdadeira inovação político-territorial com características institucionais direcionadas ao exercício da contra-hegemonia norte-americana e à coesão política interna.

A transformação da IIRSA - um instrumento direcionado à integração física de mercados, direcionado por visões politicamente conservadoras atreladas ao predomínio do Banco Interamericano de Desenvolvimento - BID - em COSIPLAN apontou, de forma inovadora, para políticas territoriais em escala sul-americana direcionadas não apenas aos elos de ligação física entre os Estados nacionais, mas também a entendimentos de que investimentos provindos de diversas escalas de poder e gestão poderiam mudar os usos políticos e econômicos do território sulamericano tanto de regiões desenvolvidas quanto das periféricas e subdesenvolvidas. Pretendeu-se que o planejamento do COSIPLAN pudesse, de alguma forma, contribuir para a diminuição de assimetrias e fraturas territoriais. A perspectiva das assimetrias remeteu à indagação em que medida ocorrem transformações em regiões periféricas, o que ainda é questão em aberto à investigação.

O exame dos três casos empíricos revelouse fortemente elucidativo do que pode e o que não pode ser uma região periférica no interior da América do Sul. As observações de campo em duas regiões, em Cuyo, Argentina e no Escudo das Guianas, possibilitou percorrer grandes distâncias rodoviárias para descobrir conteúdos que pouco são conhecidos, mesmo por geógrafos, como é o caso dos parques naturais de Talampaya e Ischigualasto ao lado da Ruta Nacional 150 na região pé-andina bem como no interior amazônico da Guiana Francesa, Suriname e República Cooperativa da Guiana.

Não foi intenção neste artigo apontar uma metodologia de identificação de regiões periféricas na América do Sul. Esta, com certeza, se tornará uma outra demanda para a análise territorial em breve. Entretanto, a partir de projetos de infraestrutura foi possível aproximar-se de algumas regiões definidas geograficamente com é o caso de Cuyo, na Argentina. O caso boliviano, por sua vez, é importante não apenas para evidenciar as contradições e discrepâncias do processo de integração sul-americano, mas também para evidenciar que atores territoriais locais e regionais deveriam fazer parte da agenda da integração. Entretanto, estes atores, como o estudo de caso evidenciou, vêm sendo desprezados por atores hegemônicos que representam interesses e poderes nacionais e/ou supranacionais.

Já o estudo de caso no Escudo das Guianas, reconhecidamente uma macrorregião extensa e complexa, só muito recentemente abordada na literatura geográfica brasileira, mostrou o quanto regiões periféricas podem estar em descompasso com a agenda supranacional da UNASUL. Enquanto o Eixo MERCOSUL-Chile através do estudo de caso da Corredor Bioceânico Porto Alegre - Coquimbo e da Ruta Nacional 150 exemplificou o verdadeiro "núcleo geoeconômico" entre o sudeste e o sul do Brasil, o centro da Argentina e os portos do Pacífico no Chile, com importantes processos de mudança de usos políticos e econômicos do território e de processos de transfronteirização, o Eixo do Escudo das Guianas demonstra o quanto o isolamento geográfico - pelas distâncias e pela presença da Floresta Amazônica - ainda é imperativo e determinante em processos de decisão governamentais e supranacionais. 
Talvez não seja demasiado concluir que algumas repercussões territoriais da IIRSA-COSIPLAN no Escudo das Guianas sejam praticamente nulas, resguardando-se, principalmente, duas pontes internacionais concluídas e a instalação de fibra ótica entre a Venezuela e o norte do Brasil.

A rigor, poder-se-ia afirmar que há mais espaços opacos e regiões periféricas na América do Sul do que regiões que tenham recebido de bancos e governos nacionais estímulos para alterar os perfis geoeconômicos do vasto interior empobrecido. A tendência atual é destes governos voltarem a seguir os preceitos do Consenso de Washington, do Banco Interamericano de Desenvolvimento - BID - e do Banco Mundial, conforme se demonstrou, com programas neoliberais e privatistas. $\mathrm{O}$ Brasil, país que vinha liderando o processo integracionista na região, atualmente ausentase da política externa e da UNASUL. Além disso, as denúncias de corrupção generalizada em obras de infraestruturas de conexão praticamente têm inviabilizado muitos projetos que vinham sendo financiados pelo BNDES, com a exportação de serviços de empresas brasileiras.

Não bastasse o retorno ao neoliberalismo de vários governos da região, a preconização da renovação do regionalismo aberto pelo Banco Mundial é um anúncio do rápido retorno da América do Sul à condição de satélite na órbita de influência norte-americana. Às regiões periféricas poderá restar o destino da continuidade do estado de isolamento e de miséria de uma população que tradicionalmente são os deserdados da terra sul-americana.

A fluidez territorial almejada deverá, em grande medida, ainda ser talvez um dos desafios principais, visto que as fraturas entre os Estadosnação, principalmente entre o Brasil e seus vizinhos, continuarão existindo, visto se tratar de situações crônicas seculares. A infraestrutura estratégica vertida para o exterior deverá continuar a constar na pauta da integração de mercados para aproximar a região-continente dos mercados da Bacia do Pacífico. Já a macrorregião transfronteiriça da Bacia do Prata, por sua vez, continuará a ser a mais importante da América do Sul, visto o grande número de cidades gêmeas e de permeabilidades entre Brasil, Uruguai, Paraguai e Argentina, enquanto regiões como o Escudo das Guianas continuarão como uma espécie de utopia da integração sul-americana, permanecendo mais próxima da região do Caribe não apenas pelo fator distância mas também por sua identidade territorial. Somente a conjuntura econômica internacional dirá se grandes empresas, dentre elas as chinesas, farão investimentos como o da construção do túnel de Água Negra nos Andes, provavelmente a obra mais importante da Agenda de projetos prioritários de integração do COSIPLAN.

\section{Referências}

ABTI. Associação Brasileira de Transportadores Internacionais. Disponível em: <http://www.abti.com.br/>. Consultas em: agosto de 2017.

ADGHIRNI, Samy. U.S. Military Agreement With Brazil to Prompt Joint Defense Deal. Disponível em: <https://www. bloomberg.com/news/articles/2017-03-23/u-s-militaryagreement-with-brazil-to-prompt-joint-defense-deal > Consulta em: 23.mar.2017.

AKYÜZ, Yllmaz; YU III, Vicente P. The financial crisis and the global south: impact and prospect. Genèva: South Centre Research Pape76, May 2017. Disponível em: <https:// www.southcentre.int/wp-content/uploads/2017/05/ RP76_The-Financial-Crisis-and-the-Global-SouthImpact-and-Prospects_EN.pdf>. Consulta em: 15.jul.2017.

ALADI - Associação Latinoamericana de Integração. Sistema de informação de Comércio Exterior - Estatísticas por item tarifario de um país. Disponível em: <http:// consultawebv2.aladi.org/sicoexV2/jsf/comercio_ exterior_item_arancelario.seam>. Consultas em: fevereiro de 2017.

ARIÑEZ, Rubén. Evo anuncia que la carretera que atraviesa el TIPNIS 'se realiza'. La Razon Nacional. 05 de junio de 2015. Disponível em: <http://www.la-razon.com/nacional/ Evo-carretera-atraviesa-TIPNIS-realiza_0_2283971614. html $>$. Consulta em: 15.mar. 2016

BALMACEDA, Raúl R. et al. Geografías de la Argentina. Buenos Aires: A-Z Editora S.A. 1997. 233 p.

BARRETTO, Annibal. Fortificações do Brasil. Rio de Janeiro: Biblioteca do Exército, 2010. 207 p.

BANCO Inter-Americano de Desarrollo. Evaluación de la Acción del BID en la Iniciativa para la Integración de la Infraestructura Regional Suramericana (IIRSA). Washington, D.C., Abril de 2008. P. V. Disponível em: <http://services.iadb.org/wmsfiles/products/ Publications/1524534.pdf >. Consulta em: 12.abr.2017. 
BANDEIRA, Luiz A.M. As políticas neoliberais e a crise na América do Sul. Revista Brasileira de Política Internacional 45(2): 135-146 [2002]. Disponível em: <http://www.scielo.br/scielo.php?script=sci_arttex t\&pid=S0034-73292002000200007 >. Consulta em: 10.fev.2017.

BARRIENTOS, Santalla et alii. Geopolítica expansionista de la Republica del Brasil y su consigna de marcha haciael Oeste. La Paz: Escuela de Altos Estudos Nacionales, 1991, p. 28 apud BRUSLÉ, Lætitia P. La dernière frontière. Loin des Andes, trop près du Brésil. La frontière orientale et la construction du territoire en Bolivie. Paris: Université de Paris I, Panthéon Sorbonne, Institut de Géographie, 2005. p. 484.

BARROCAL, André. Delação da Odebrecht nos EUA sacode a América Latina. Carta Capital. Disponível em: https:// www.cartacapital.com.br/internacional/delacao-daodebrecht-nos-eua-sacode-a-america-latina. Consulta em: 02.jul.2017.

BBC BRASIL. O ambicioso projeto da Argentina e do Chile para construir otúnel mais longo da América Latina. Disponível em: <http://www.bbc.com/portuguese/ internacional-40134174>. 2 junho 2017. Consulta em: 12.jun.2017.

BENITES,Afonso.Brasil começa a enviar delação da Odebrecht a 8 países da região. El País. Disponível em: <https://brasil.elpais.com/brasil/2017/06/02/ politica/1496438612_350750.html $>$. Consulta em: 05.jul.2017.

BOLÍVIA promulga lei que veta construção de estrada financiada pelo Brasil. Folha de São Paulo. 25.out.2011. Disponível em: <http://m.folha.uol.com.br/ mundo/2011/10/996110-bolivia-promulga-lei-queveta-construcao-de-estrada-financiada-pelo-brasil. shtml>. Consulta em: 02.mar.2017.

BOWN, Chad P. etalii. Better Neighbors. Toward a Renewal of Economic Integration in Latin America. Washington, World Bank Group, 2017. Disponível em: <https:// openknowledge.worldbank.org/handle/10986/25736>. Consulta em: 30.jul.2017.

BRASIL. Programa de Promoção do Desenvolvimento da Faixa de Fronteira - PDFF. Brasília: Ministério da Integração Nacional, 2009. $64 \mathrm{p}$.

BRASIL. Instituto Brasileiro de Geografia e Estatística. Disponível em: <http://www.ibge.gov.br/>. Consulta em: 10 set. 2017.

BRASIL e mais cinco países suspendem participação na Unasul. Istoé. 22.abr.2018. Disponível em: Disponível em: <https://istoe.com.br/brasil-e-mais-cinco-paisessuspendem-participacao-na-unasul/> $>$ Consulta em: 23.abr.2018.

BRUSLÉ, Lætitia P. La dernière frontière. Loin des Andes, trop près du Brésil. La frontière orientale et la construction du territoire em Bolivie. Paris: Université de Paris 1, Panthéon Sorbonne, Institut de Géographie, 2005.
BURGARDT, Victor H. Veppo. A nação nas fronteiras longínquas: o sentimento nacional dos pampas ao lavrado. In: Fronteiras em movimento. Fábio Régio Bento (org.). Jundiaí: Paco Editorial, 2012, pp. 103-121.

BURGARDT, Victor H. Veppo. Nações e resistência ao sul do Orinoco. A construção política e imaginária do índio. Jundiaí: Paco Editorial, 2013. 209 p.

CABALLERO, Natalia. Obra binacional. Cuáles sonl as empresas interesadas en construir el Túnel de Agua Negra. Tiempo de San Juan. Disponível em: <http:// www.tiempodesanjuan.com/politica/2017/6/1/ cuales-empresas-interesadas-construir-tunel-aguanegra-178351.html>. Consulta em: 20.jun.2017.

CARWIL B-J. Bolivian-Venezuelan Military construction team begins work on TIPNIS highway. Carwil without Borders. Disponível em: <https://woborders. blog/2015/06/29/bolivian-venezuelan-militaryconstruction-team-begins-work-on-tipnis-highway/>. Consulta em : 16.mar.2017.

CEPAL. El regionalismo abierto em America Latina y el Caribe. La integración económica al servicio de la transformación productiva com equidade. Santiago de Chile, 1994. Disponível em: <http://repositorio.cepal.org/bitstream/ handle/11362/2140/1/S9481108_es.pdf >. Consultas em: janeiro de 2017.

CIA. Central Intelligence Agency. The World Factbook. Disponível em: <https://www.cia.gov/library/ publications/the-world-factbook/>. Consulta em: 10.set. 2017.

CONDE, Philippe. Les BIC : entre émergence et crise de croissance. Diploweb. samedi 28 janvier 2017. Disponível em: <http://www.diploweb.com/Les-BIC-entreemergence-et-crise.html>. Consulta em: 02.jul.2017.

CONECTAS. Direitos Humanos. Denúncia da Sociedade Civil ao BNDES por sua participação no Projeto de Rodovia Villa Tunari-San Ignacio de Moxos (Bolívia). São Paulo - La Paz - Londres, 20 de Outubro de 2015. Disponível em: Disponivel em: <http://www.conectas.org/arquivos/ editor/files/Conectas_GW_Cedla\%20-\%20Denuncia\%20 Ouvidoria\%20BNDES\%20-\%20Villa\%20Tunari-\%20 San\%20Ignacio\%20Moxos_20_10_2015.pdf>. Consultas em: fevereiro de 2017.

CONFEDERAÇÃO Nacional da Indústria - CNI. Desafios para a integração logística na América do Sul. Brasília: Confederação Nacional da Indústria / Armando Castelar. 2015. Disponível em: <http://staticcms-si.s3.amazonaws.com/legacy/app/conteu do_18/2016/03/02/10642/0203-EstudoDesafiospar aaIntegraoLogsticadaAmericadoSul.pdf $>$. Consultas em: junho de 2017.

CORAZZA, Gentil. O "regionalismo aberto" da CEPAL e a inserção da América Latina na globalização. Ensaios FEE, Porto Alegre, v. 27, n. 1, p. 135-152, maio 2006. Disponível em: <http://revistas.fee.tche.br/index.php/ ensaios/article/viewFile/2114/2496>. Consultas em: fevereiro de 2017. 
COSIPLAN. Cartera 2016. Disponível em: <https:// www.flipsnack.com/IIRSA/informe-de-la-cartera-deproyectos-del-cosiplan-2016.html .

COSIPLAN. API. Agenda de projetos prioritários de integração. 2016. Disponível em: <http://www.iirsa.org/admin iirsa_web/Uploads/Documents/api_agenda_de_ projetos_port.pdf >. Consultas em: 2017.

COSTA, Rogério S. da. A América do Sul vista do Brasil: a estratégia de integração do Governo Lula. Porto Alegre: UFRGS / Programa de Pós-Graduação em Ciência Política, 2010. (Tese de Doutorado). Disponível em: <http://www. lume.ufrgs.br/handle/10183/54096>.

COSTA, Wanderley M. da. O Brasil e a América do sul: cenários geopolíticos e os desafios da integração. Confins [Online], 7 | 2009, posto online no dia 31 Outubro 2009. Disponível em: <http://confins.revues. org/6107>. DOI : $10.4000 /$ confins.6107

DINIZ, Rubens. O Brasil e o Conselho de Defesa SulAmericano. Carta Capital. 24/02/2015. Disponível em: <https://www.cartacapital.com.br/blogs/blog-do-grri/ o-brasil-e-o-conselho-de-defesa-sul-americano-1178. html>. Consulta em: 18.set.2017.

FERNANDEZ, Victor R. Explorando las limitaciones del nuevo regionalismo en las politicas de la Unión Europea: una perspectiva latino-americana. Revista EURE (Vol. XXXIII, No 98), pp. 97-118, Santiago de Chile, mayo de 2007. Disponível em: <http:// www.scielo.cl/scielo.php?script=sci_arttext\&pid $=$ S0250-71612007000100006 >. Consultas em: 2016 e 2017.

FONSECA, Bruno; MOTA, Jessica. Pan amazônia à Brasileira. Amazônia. 23/nov/2013. Disponível em: <http:// amazonia.org.br/2013/11/pan-amaz\%C3\%B4nia\%C3\%A0-brasileira/>. Consulta em: 15.mar.2017.

FOWKS, Jacqueline Kuczynski. "Não há como negar que o caso Odebrecht é um freio para a economia". El País. Disponível em: <https://brasil.elpais.com/ brasil/2017/03/10/internacional/1489108861_588085. html.10.mar.2017>. Consulta em: 02.jul.2017.

GUMUCIO M. Baptista et WEISE A, Saavedra. Antologia geopolitica de Bolivia. La Paz: Los amigos del Livro, 1978, p. 105 apud BRUSLÉ, Lætitia P. La dernière frontière. Loin des Andes, trop près du Brésil. La frontière orientale et la construction du territoire em Bolivie. Paris: Université de Paris 1, Panthéon Sorbonne, Institut de Géographie, 2005. p. 484.

INDEX MUNDI. Bolívia. Historical Data Graphs per Year. Disponível em: <http://www.indexmundi.com/g/g. aspx?v=21\&c=bl\&l=en $>$.Consulta em: 21.ago.2017

INTEROCEÂNICA permitiu crescimento do comércio entre Brasil e Peru. Jornal da USP. Disponível em: <https:// jornal.usp.br/ciencias/ciencias-humanas/interoceanicapermitiu-crescimento-do-comercio-entre-brasil-eperu/>. Consulta em: 03.ago.2017.

JIMENEZ P., Georgina. La carretera. ¿A quién beneficia. Villa Tunari-San Ignacio de Moxos. Petropress, 27/11/2011.
Disponível em: <https://www.academia.edu/3292142/ La_carretera_Villa_Tunari_San_Ignacio_de_Moxos_A_ qui\%C3\%A9n_beneficia.petropress $>$. Consulta em: 02.mar.2017.

KALOUT, Hussein. Ausência de estratégia para América do Sul compromete ambições do Brasil. Disponível em: <http://www1.folha.uol.com.br/colunas/husseinkalout/2017/01/1852198-brasil-precisa-reformularuma-estrategia-para-a-america-do-sul.shtml >. Consulta em: 13.fev.2017.

LÍRIO, Sérgio "A passagem de José Serra pelo Itamaraty foi desastrosa". Carta Capital. 17.mar.2017. Disponível em: <https://www.cartacapital.com.br/internacional/apassagem-de-jose-serra-pelo-itamaraty-foi-desastrosa〉. Consulta em: 02.mai.2017

LISBOA, Camila. Parque nacional Talampaya: um lugar que você não conhece na Argentina. S.d. Disponivel em: Disponível em: <http://www.omelhormesdoano.com/ parque-nacional-talampaya/>. Consulta em: 12.jun.2017.

MANETTO, Francesco. Aliança do Pacífico incorpora mais quatro países. El País. Disponível em: <https://brasil.elpais.com/brasil/2017/07/01/ internacional/1498863536_644235.html >.01/jul/2017. Consulta em: 30.jul.2017.

MARTINEZ, Paola. Bolivia frente a la IIRSA-COSIPLAN? Entre el extractivismo y la integración? Buenos Aires: CLACSO, 2013. Disponível em: Disponível em: <http:// biblioteca.clacso.edu.ar/clacso/becas/20131016053606/ Informe.pdf >. Consultas em: março de 2017.

MELO, Liana. Militares americanos na Amazônia causam discórdia no Exército brasileiro. Projeto \#Colabora. 21.jul.2017. Disponível em: Disponível em: <http:// projetocolabora.com.br/florestas/gringos-de-farda-naamazonia-amazonlog/>. Consulta em: 30.jul.2017.

MONTOYA, Rodrigo B. Darle sepultura a Unasur. El Colombiano. Disponível em: <http://www.elcolombiano. com/opinion/columnistas/darle-sepultura-a-unasurAL6728020 >. Consulta em: 12.jul.2017.

NASCIMENTO, Luciano. EUA participam como observadores de exercício militar na Amazônia. EBC Agência Brasil. Disponível em: <http://agenciabrasil.ebc.com.br/geral/ noticia/2017-11/eua-participam-como-observadoresde-exercicio-militar-na-amazonia>. Consulta em: 19.mar.2018.

NERY, Tiago. UNASUL: a dimensão política do novo regionalismo sul-americano. Cadernos $C R H$, Salvador, v. 29, n. SPE 03, p. 59-75, 2016. Disponível em: <http://www.scielo.br/scielo.php?script=sci arttext\&pid=S0103-49792016000600059\&lng=pt\&tl ng=pt $>$. Consulta em: 10.jan.2017.

OLIVEIRA, Alessandra G. Do velho ao novo regionalismo: evolução das políticas conjuntas para o desenvolvimento planejado da América Latina. Santiago do Chile: ILPES/ CEPAL, 2014. Disponível em: <http://www.cepal.org/ pt-br/publicaciones/36664-velho-novo-regionalismo- 
evolusao-politicas-conjuntas-o-desenvolvimentoplanejado >. Consultas em: fevereiro de 2017.

OLIVEIRA, Rafael da Silva. Mobilidades transgressoras, geografias ignoradas: itinerários e emaranhamentos envolvendo garimpeiros brasileiros no Suriname (Tese de Doutorado). Universidade de São Paulo. Departamento de Geografia. São Paulo: USP, 2013. 400 p.

PADULA, Raphael. Da IIRSA à COSIPLAN da UNASUL: a integração de infraestrutura na América do Sul nos anos 2000 e suas perspectivas de mudança. In: NETO, Walter A.D. (org.). O Brasil e as novas dimensões da integração regional. Rio de Janeiro: IPEA, 2014, pp. 291351. Disponível em: <http://www.ipea.gov.br/agencia/ images/stories/PDFs/livros/livros/livro_brasil_novas_ dimensoes.pdf >. Consultas em: fevereiro de 2017.

PAZ, Gabrielle. Integração da América do Sul: o BNDES como agente da política regional do governo Lula. $1^{\circ}$ Seminário Internacional de Ciência Política. Estado e democracia em mudança no século XXI. Porto Alegre: UFRGS, 1-11 Setembro de 2015. Disponível em: <https://www.ufrgs. br/sicp/wp-content/uploads/2015/09/PAZ-2015Integra\%C3\%A7\%C3\%A3o-da-Am\%C3\%A9rica-doSul.pdf>.

PECEQUILLO, Cristina S. 2016.0 reposicionamento estratégico dos Estados Unidos na América do Sul. In: PASSOS, Rodrigo D. F.; FUCCILLE, Alexandre (orgs).Visões do Sul: crise e transformações do sistema internacional. Marília: Oficina Universitária; São Paulo: Cultura Acadêmica, 2016, pp 229-246. Disponível em: Disponível em: <https://www.marilia.unesp.br/Home/ Publicacoes/visoes-do-sul_vol.1-ebook.pdf $>$. Consultas em: março de 2017.

PEREIRA CARNEIRO, Camilo. Radiografia contemporânea dos Arcos Norte e Sul da fronteira do Brasil. In: Fronteiras e relações Brasil-Uruguai. Maria Izabel Mallmann \& Teresa C. S. Marques (orgs.). Porto Alegre: EdiPUCRS, 2015, pp. 129-146.

PFRIMER, Matheus H.Heartland Sul-americano?Dos discursos geopolíticos à territorialização de um novo triângulo estratégico boliviano. GEOUSP - Espaço e Tempo, São Paulo, n.29, pp. 131-144, 2011. Disponível em: <https://www.revistas.usp.br/geousp/article/ view/74192>. Consulta em: outubro de 2016.

PREBISCH, Raúl. O desenvolvimento econômico da América Latina e alguns dos seus problemas principais. In: BIELSCHOWSKY, Ricardo (org). Cinquenta anos de pensamento na CEPAL. Rio de Janeiro: Editora Record, 2000. Volume 1. Disponível em: <http://archivo.cepal. org/pdfs/cdPrebisch/123.pdf >. Consultas em: março de 2017.

PRONUNCIAMENTO PÚBLICO de la Sub-Central de Mujeres Indigenas del Territorio Indigena Parque Nacional Isiboro SecureTipnis. Sub central de pueblos indígenas. Trinidad, 04.mar.2017. Disponível em: <https://pt.scribd.com/ document/341667117/Subcentral-Mujeres-de-TIPNIS-
Pronunciamiento-3-Marzo-2017\#fullscreen\&from embed>. Consulta em: 12.mai. 2017.

PORTO, Jadson L. R. A condição periférico-estratégica da Amazônia Setentrional: a inserção do Amapá no Platô das Guianas In: Jadson L. R. Porto \& Durbens M. Nascimento (orgs.). Interações fronteiriças no Platô das Guianas: novas construções, novas territorialidades. Rio de Janeiro: Publit, 2010, pp. 139-160.

QUATRO cantos do mundo. Lugares Únicos no Mundo - Parque NacionalTalampaya-Argentina. Disponível em: <https:// quatrocantosdomundo.wordpress.com/2015/03/15/ lugares-unicos-no-mundo-parque-nacional-talampayaargentina/>. Consulta em: 15.jul.2017.

RAFFESTIN, Claude. Por uma geografia do poder. São Paulo, Ática, 1993.

RAMOS, Victor A. Las provincias geológicas del territorio argentino. Geología Argentina. Instituto de Geología y Recursos Minerales, Anales 29(3): 41-96, Buenos Aires, 1999.

ROSIÈRE, Stéphane. Géographie politique \& Géopolitique. Une grammaire de l'espace politique. $2^{e}$ édition. Paris: Ellipses Édition, 2007.

RUTA NACIONAL 150: una de las mas complejas del pais. Revista Vial. Disponível em: <http://revistavial.com/ index.php/publicaciones/2013/revista-94/item/1833ruta-nacional-150-una-de-las-mas-complejas-del-pais > . Consulta em 12.jun.2017.

SANCHEZ, Eugení. Geografía Política. Madrid: Editorial Síntesis, 1992. $224 \mathrm{p}$.

SANTOS, Milton; SILVEIRA, María Laura. O Brasil. Território e sociedade no início do século XXI. 5. ed., Rio de Janeiro: Record, 2003. 474 p.

SCHILLING, Paulo. Oexpansionismo brasileiro. A geopolítica do General Golbery e a diplomacia do Itamaraty. São Paulo: Global Editora e Distribuidora Ltda, 1981. 288 p. SILVA, Golbery do Couto e. Conjuntura política nacional, o Poder Executivo \& Geopolítica do Brasil. 3. ed., Rio de Janeiro: Livraria José Olympio Editora, 1981. 273 p.

SILVA, Gutemberg de Vilhena. Usos contemporâneos da fronteira franco-brasileira: entre os ditames globais e a articulação local. Macapá: Editora da UNIFAP, 2014. $131 \mathrm{p}$.

SISTEMA FIERGS. Corredor Bioceânico Central ampliará logística para escoamento dos produtos gaúchos. Disponível em: <http://www.fiergs.org.br/pt-br/noticia/corredorbioceanico-central-ampliara-logistica-para-escoamentodos-produtos-gauchos >. Consulta em: 12.jun.2017.

SOUZA, César W. Batista. O sonho bolivariano. $62^{a}$ Reunião Anual da SBPC, 2010. Disponível em: <http://www. sbpcnet.org.br/livro/62ra/resumos/resumos/1090. htm>. Consulta em: 13.mar.2017.

SPALETTI, L.A. Cuencas triásicas del Oeste argentino: origen y evolución. Acta Geologica Hispanica, v. 32 (1997), no 1-2, p. 29-50 (Pub. 1999).

SPEKTOR, Matias. Estilo ativista de José Serra enfrentou obstáculos. Folha de São Paulo. Ed. 24.fev.2017. 
Disponível em: <http://www1.folha.uol.com.br/colunas/ matiasspektor/2017/02/1861565-estilo-ativista-dejose-serra-enfrentou-obstaculos.shtml $>$. Consulta em: 12.mai.2017

TOLA, Raúl. Ex-presidente do Peru Ollanta Humala é preso por corrupção no caso Odebrecht. El País. 14.jul.2017. Disponível em: <https://brasil.elpais.com/ brasil/2017/07/14/internacional/1500001602_001817. html >.Consulta em: 25.jul.2017.

TRAVASSOS, Mário. Projeção Continental do Brasil. 2a.ed. ampl. São Paulo: Companhia Editoria Nacional, 1935.
UEBEL, Roberto G. Fronteras e inmigración contemporánea en Brasil: el caso de la inmigración boliviana. Mundi Migratios. v. 3, n. 2, Pág. 92-111, 2015. Disponível em: <http://www.anuariocemi.uh.cu/index.php/MMig/ article> Consulta em: 12.ago.2017.

WORLD Bank. GDP (current US\$). All countries and Economies. Disponível em: <http://data.worldbank. org/indicator/NY.GDP.MKTP.CD >. Consulta em: 21.ago.2017.

\footnotetext{
* Este artigo contou com o apoio de recursos dos projetos de pesquisa "Políticas territoriais comparadas União Europeia-América do Sul (CNPq) e "Transfronterizações na América do Sul. Dinâmicas territoriais, desenvolvimento regional, integração e defesa nas fronteiras meridional e setentrional do Brasil” (CAPES-Pró-Defesa). Foram desenvolvidas observações de campo pelos autores na Argentina e no Escudo das Guianas entre 2013 e 2017.
}

\section{Aldomar Arnaldo Rückert}

Professor Doutor (USP, 2002) no Departamento de Geografia e nos programas de pós-graduação em Geografia e em Planejamento Urbano e Regional da Universidade Federal do Rio Grande do Sul (UFRGS). Pesquisador CNPq, nível 2. Doutor em Ciências: Geografia Humana pela Universidade de São Paulo (2002) com Estágio de Pós-doutorado na Universidade Paris 7 Denis Diderot (2011). Líder do grupo de pesquisa LABETER Laboratório Estado e Território. Gestão, regiões e fronteiras. É um dos fundadores da Rede Brasileira de Geografia Política, Geopolítica e Gestão do Território (REBRAGEO). Membro do Conselho Científico do CIST - Collège Inernational des Sciences du Territoire, Universidades Paris 7 Denis Diderot e Paris 1 Panthéon Sorbonne. E-mails: aldomar.ruckert@gmail.com; aldomar.ruckert@ufrgs.br

\section{Camilo Pereira Carneiro}

Doutor em Geografia (UFRGS, 2013). Atualmente é professor visitante da UFGD (Universidade Federal da Grande Dourados, MS), atuando no Mestrado em Fronteiras e Direitos Humanos da Faculdade de Direito e Relações Internacionais. Pesquisador do grupo LABETER (Laboratório Estado e Território. Gestão, regiões e fronteiras) da UFRGS. Autor do livro "Fronteiras irmãs: transfronteirizações na Bacia do Prata".

E-mail: pereiracarneiro.camilo@gmail.com 